\title{
SUPPORT OF AQUATIC LIFE USES IN THE UPPER BLACKFOOT RIVER AND TRIBUTARIES \\ BASED ON THE COMPOSITION AND STRUCTURE OF THE BENTHIC ALGAE COMMUNITY
}

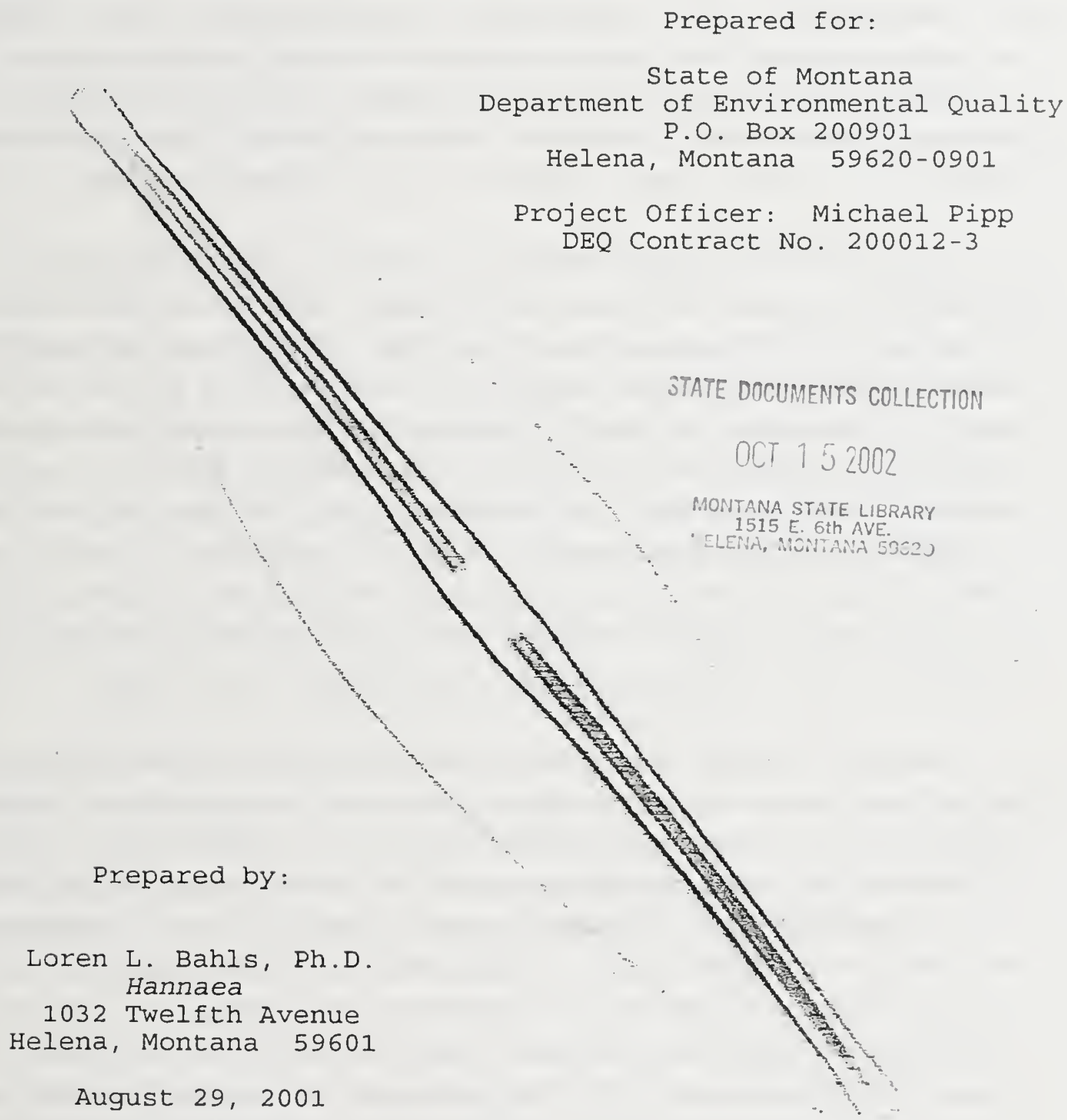




\section{SUMMARY}

In June of 2001, 12 periphyton samples were collected from the Blackfoot River above Nevada Creek and from four tributaries of the upper Blackfoot River in western Montana for the purpose of assessing whether these streams are water-quality limited and in need of TMDLs. The samples were collected following DEQ standard operating procedures, processed and analyzed using standard methods for periphyton, and evaluated following modified USEPA rapid bioassessment protocols for wadeable streams.

Diatoms with deformities were found in periphyton samples collected from all 12 sites on the upper Blackfoot River and tributaries. In samples from two sites--BlckftR-01 and SbrC-02-teratological diatoms accounted for more than 10\% of the cells that were counted, indicating severe impairment and nonsupport of aquatic life uses. At five sites--BlckftR-02, SbrC-01, AraC-01, PoorC-02, and PoorC-01--the percentage of teratological cells indicated moderate impairment and partial support of uses. The most likely cause of this impairment is elevated concentrations of heavy metals. The remaining 5 sites suffered only minor impairment and fully supported their aquatic life uses.

In addition to having large percentages of teratological cells, the two sites on Sandbar Creek also supported very large populations of individual diatom species. At SbrC-02, Achnanthidium minutissimum accounted for $86 \%$ of the cells in the diatom association. Streams receiving mining wastes in western Montana often support very large numbers of Achnanthidium minutissimum, an indicator of chemical disturbance and elevated concentrations of heavy metals. The upstream site on Sandbar Creek (SbrC-01) supported a large number of Diatoma mesodon, a cold-water stenotherm that is common in streams receiving mine adit discharge water and flows recharged by groundwater. 


\section{INTRODUCTION}

This report evaluates the biological integrity, support of aquatic life uses, and probable causes of impairment to those uses, in the upper Blackfoot River and in four tributaries of the upper Blackfoot River in western Montana. The purpose of this report is to provide information that will help the state of Montana determine whether these streams are water-quality limited and in need of TMDLs.

The federal Clean water Act directs states to develop water pollution control plans (Total Maximum Daily Loads or TMDLs) that set limits on pollution loading to water-quality limited waters. Water-quality limited waters are lakes and stream segments that do not meet water-quality standards, that is, that do not fully support their beneficial uses. The Clean water Act and USEPA regulations require each state to (1) identify waters that are water-quality limited, (2) prioritize and target waters for TMDLs, and (3) develop TMDL plans to attain and maintain waterquality standards for all water-quality limited waters.

Evaluation of use support in this report is based on the species composition and structure of the periphyton (benthic algae, phytobenthos) community at 12 sites that were sampled from mid to late June in 2001. The periphyton community is a basic biological component of all aquatic ecosystems. Periphyton accounts for much of the primary production and biological diversity in Montana streams (Bahls et al. 1992).

Plafkin et al. (1989) and Stevenson and Bahls (1999) list several advantages of using periphyton in biological assessments:

Algae are universally present in large numbers in all streams and unimpaired periphyton assemblages typically support a large number $(>30)$ of species; 
- Algae have rapid reproduction rates and short life cycles, making them useful indicators of short-term impacts;

- As primary producers, algae are most directly affected by physical and chemical factors, such as temperature, nutrients, dissolved salts, and toxins;

- Sampling is quick, easy and inexpensive, and causes minimal damage to resident biota and their habitat;

- Standard methods and criteria exist for evaluating the composition, structure, and biomass of algal associations;

- Identification to species is straightforward for the diatoms, for which there is a large body of taxonomic and ecological literature;

- Excessive algae growth in streams is often correctly perceived as a problem by the public.

- Periphyton and other biological communities reflect the biological integrity of waterbodies; restoring and maintaining the biological integrity of waterbodies is a goal of the federal Clean water Act;

- Periphyton and other biological communities integrate the effects of different stressors and provide a measure of their aggregate impact; and

- Periphyton and other biological communities may be the only practical means of evaluating impacts from non-point sources of pollution where specific ambient criteria do not exist (e.g., impacts that degrade habitat or increase nutrients).

Periphyton is a diverse assortment of simple photosynthetic organisms called algae, and other microorganisms that live attached to or in close proximity of the stream bottom. Most algae, such as the diatoms, are microscopic. Diatoms are distinguished by having a cell wall composed of opaline glass-hydrated amorphous silica. Diatoms often carpet a stream bottom with a slippery brown film.

1 Biological integrity is defined as "the ability of an aquatic ecosystem to support and maintain a balanced, integrated, adaptive community of organisms having a species composition, diversity, and functional organization comparable to that of natural habitats within a region" (Karr and Dudley 1981). 
Some algae, such as the filamentous greens, are conspicuous and their excessive growth may be aesthetically displeasing, deplete dissolved oxygen, interfere with fishing and fish spawning, clog water filters and irrigation intakes, create tastes and odors in drinking water, and cause other problems.

\section{PROJECT AREA AND SAMPLING SITES}

The project area is located in Lewis \& Clark and Powell Counties in western Montana. The surface geology of the upper Blackfoot River watershed consists mostly of Precambrian Belt Series rocks in the uplands and Quaternary basin fill in the valleys (Renfro and Feray 1972).

The Blackfoot River heads near Rogers Pass (elevation 5,610 feet) north of Helena. Most tributaries arise at elevations ranging from 5,000 to 9,000 feet. At 4,300 feet, the Blackfoot River above Nevada Creek is the lowest site in the study area. Vegetation is mainly mixed conifer forest with alpine tundra on the highest peaks and open parks of fescue grassland near the mouth of Poorman Creek and near the mouth of Nevada Creek at the lower end of the study area (USDA 1976).

The upper Blackfoot River watershed is within the Northern Rockies Ecoregion of Montana (woods et al. 1999). The main land uses are recreation, livestock grazing, logging, and mining. The Blackfoot River is popular for fishing and floating, mainly below the study area. The upper Blackfoot River drainage has many abandoned mine sites and a long history of hardrock mining.

Periphyton samples were collected at 12 sites on the Blackfoot River and four of its tributaries (Maps 1-7, Table 1). Most sampling sites are on public (USFS, BLM, or state) land. The Blackfoot River and its tributaries are classified B-1 in the Montana Surface Water Quality Standards. 


\section{METHODS}

Periphyton samples were collected following standard operating procedures of the MDEQ Planning, Prevention, and Assistance Division. Using appropriate tools, microalgae were scraped, brushed, or sucked from natural substrates in proportion to the rank of those substrates at the study site. Macroalgae were picked by hand in proportion to their abundance at the site. All collections of microalgae and macroalgae were pooled into a common container and preserved with Lugol's solution.

The samples were examined to estimate the relative abundance and rank by biovolume of diatoms and genera of soft (non-diatom) algae according to the method described in Bahls (1993). Soft algae were identified using Dillard (1999), Prescott (1978), Smith (1950), and Whitford and Schumacher (1984). These books also served as references on the ecology of the soft algae, along with Palmer (1969, 1977).

After the identification of soft algae, the raw periphyton samples were cleaned of organic matter using sulfuric acid, and permanent diatom slides were prepared using Naphrax, a high refractive index mounting medium, following standard Methods for the Examination of Water and Wastewater (APHA 1998). Between 400 and 494 diatom cells (800 to 988 valves) were counted at random and identified to species. The following were used as the main taxonomic and autecological references for the diatoms: Krammer and Lange-Bertalot 1986, 1988, 1991a, 1991b; Patrick and Reimer 1966, 197.5. Lowe (1974) was also used as an ecological reference for the diatoms.

The diatom proportional counts were used to generate an array of diatom association metrics (Table 2). A metric is a characteristic of the biota that changes in some predictable way with increased human influence (Barbour et al. 1999). 
Metric values from the Blackfoot River and tributaries were compared to numeric biocriteria or threshold values developed for streams in the Rocky Mountain Ecoregions of Montana (Table 3 ). These criteria are based on metric values measured in leastimpaired reference streams (Bahls et al. 1992) and on metric values measured in streams that are known to be impaired by various sources and causes of pollution (Bahls 1993).

The criteria in Table 3 distinguish among four levels of impairment and three levels of aquatic life use support: no impairment or only minor impairment (full support); moderate impairment (partial support); and severe impairment (nonsupport). These impairment levels correspond to excellent, good, fair, and poor biological integrity, respectively.

Quality Assurance. Several steps were taken to assure that the study results are accurate and reproducible.

Upon receipt of the samples, station and sample information were recorded in a laboratory notebook and the samples were assigned a unique number compatible with the Montana Diatom Database, e.g., 2156-01. The first part of this number (2156) designates the sampling site (Blackfoot River at Flesher Pass Road); the second part of this number (01) designates the number of periphyton samples that have been collected at this site for which data have been entered into the Montana Diatom Database.

Sample observations and analyses of soft (non-diatom) algae were recorded in a lab notebook along with station and sample information provided by MDEQ. A portion of the raw sample was used to make duplicate diatom slides. After completing the diatom proportional count, the slide used for the count will be deposited in the Montana Diatom Collection at University of Montana Herbarium in Missoula. The other slide will be retained by Hannaea in Helena. 
On completion of the project, station information, sample information, and diatom proportional count data will be entered into the Montana Diatom Database.

\section{RESULTS AND DISCUSSION}

Results are presented in Figure 1 and Tables 4 through 7 , which are located near the end of this report following the Literature Cited section. Spreadsheets containing completed diatom proportional counts, with species' pollution tolerance classes (PTC) and percent abundances, are attached as Appendix A.

\section{SAMPLE NOTES}

Blackfoot River. Deformed diatom valves were noted in all three of the periphyton samples from the upper Blackfoot River.

Arrastra Creek. Algae were very sparse in the sample from AraC-01, and the usually colonial alga Hydrurus was present only as individual cells. This implies that algal colonization and succession at this site were at a very early stage.

Poorman Creek. All three of the samples from Poorman Creek were dominated by moss. Spirogyra in the sample from PoorC-03 was senescent.

Willow Creek. The sample collected at WilC-0I was dominated by moss. Ulothrix zonata was the species of Ulothrix present at WilC-02.

Sandbar Creek. The sample from SbrC-01 was dominated by moss. Algae were sparse and diatoms were very sparse in the sample from SbrC-02. 
NON-DIATOM ALGAE

Blackfoot River. Filamentous green algae dominated the periphyton community at all three sites on the upper Blackfoot River, and a different genus dominated at each site (Table 4).

Zygogonium dominated at the upstream site (Flesher Pass Road). This unusual alga, which is rare in periphyton samples, is primarily aerial and grows on moist acid soils, rocks, and peat (Smith 1950). When growing on soil, it may develop in patches several yards in diameter. "The remarkable capacity of zygogonium for taking up and returning large quantities of water plays no inconsiderable role in colonization of bare soil by the smaller phanerogams" (Smith 1950).

Diatoms ranked second in biovolume at BlckftR-01, followed by Tolypothrix, a cyanobacterium that requires cool water. In total, 12 genera of green, blue-green, and golden nondiatom algae were found in the sample from this site (Table 4). These algae indicate cool waters with relatively low levels of nutrients.

Stigeoclonium dominated the periphyton at BlckftR-02, above Landers Fork. This alga is often found in waters that are enriched with organic wastes (Palmer 1969). The source of this organic load may be swampy areas upstream or old pit toilets at the Forest Service campground (Aspen Grove) just above the sampling site (Michael Pipp, MDEQ, pers. comm.). Diatoms ranked 2nd in biovolume at this site, followed by the cyanobacterium Nostoc, which indicates cool waters where nitrogen is limiting. A total of 9 genera of non-diatom algae in three divisions were recorded at this site (Table 4 ).

Ulothrix dominated the periphyton community at BlckftR-03, above Nevada Creek, followed by the cyanobacterium Oscillatoria. These algae indicate increasing nitrogen enrichment. Diatoms 
ranked 3 rd at this site. Ten genera of non-diatom algae were recorded here, in four different divisions, including the red alga Audouinella (Table 4).

Poorman Creek. Diatoms dominated the periphyton community in all three samples from Poorman Creek (Table 4). Cyanobacteria ranked second at the upper two sites: Nostoc at PoorC-01 and Phormidium at PoorC-02. These genera indicate cool waters with relatively low levels of nutrients. The filamentous green alga Spirogyra ranked second at Poorc-03. This alga, also known as "pond scum", indicates warmer water temperatures, which may be due to a large beaver dam complex just upstream (Michael Pipp, $M D E Q$, pers. comm.).

The number of non-diatom genera was lower in Poorman Creek than in the upper Blackfoot River: only 2 to 6 genera of nondiatom algae were recorded at each site (Table 4). This may be due to the smaller size of Poorman Creek and natural stresses associated with shading and cool waters of low mineral content. Diatoms, green algae, and cyanobacteria were present at PoorC-01, whereas only diatoms and cyanobacteria were present at PoorC-02. Cyanobacteria were absent at the downstream site (PoorC-03), but green algae and red algae were present here (Table 4).

Arastra Creek. On average, Arrastra Creek supported even fewer non-diatom algae than did poorman Creek (Table 5). Only diatoms and the cold-water chrysophyte Hydrurus foetidus were found with regularity in the sample from AraC-01. Hydrurus dominated the sample from AraC-02, followed by diatoms and the filamentous green alga Ulothrix. These algae indicate cold waters with relatively low levels of nutrients.

Sandbar Creek. Diatoms dominated the periphyton sample collected at SbrC-OI and the cyanobacterium Phormidium accounted for the most biovolume at SbrC-02 (Table 5). Among the non- 
diatom algae, both sites supported a mix of green algae and cyanobacteria, and a single genus of chrysophyte (Tribonema). Ten genera of non-diatom algae were found at the upstream site and seven genera at the downstream site (Table 5). As with the other streams in this study, the algal flora of Sandbar Creek indicated cool waters of low mineral content.

Willow Creek. Diatoms accounted for most of the biovolume in the periphyton sample collected at WilC-0I and the chrysophyte Tribonema ranked second at this site (Table 5). Nine other genera of green algae and cyanobacteria, most of them indicating cool waters of low nutrient and low mineral content, made up the rest of the flora.

The filamentous green alga Ulothrix dominated the periphyton sample from wilC-02, followed by Chaetophora (filamentous green), Audouinella (filamentous red), and Tolypothrix (filamentous cyanobacterium) (Table 5). These algae also indicate cool waters with relatively low nutrient and mineral content.

\section{DIATOMS}

Blackfoot River. Most of the major diatom species in samples from the upper Blackfoot River are sensitive to organic enrichment (Table 6). However, Synedra rumpens, the dominant species at the Flesher Pass Road, is somewhat tolerant of organic loading (Lange-Bertalot 1979). Organic loading at this site, which is also reflected by the borderline pollution index (2.50), may be internal and due to the naturally swampy nature of the stream at and above this location.

Aside from minor organic loading and disturbance, and a slightly elevated percent dominant species value at the upstream site, the most serious problem in the upper Blackfoot River 
appears to be chronic metals toxicity resulting in large percentages of abnormal diatom valves (Table 6). The largest of these percentages (11.40\%) is comparable to that found in the Eagle River of Colorado, a federal superfund site (McFarland et al. 1997). Large percentages of teratological diatom valves have also been observed in Tenmile Creek near Helena (Bahls 1998) and in Elkhorn Creek near Wise River (Bahls 2001). Both sites have elevated heavy metals associated with historic mining activities.

The percentage of abnormal diatom valves in the upper Blackfoot River decreases in a downstream direction (Figure 1, Table 6). This likely indicates dilution of heavy metals by cleanwater tributaries and/or an increase in buffering capacity as the river becomes more alkaline. The percentage of abnormal valves at the Flesher Pass Road (BlckftR-01) indicates severe impairment and nonsupport of aquatic life uses. The percentage above the Landers Fork (BlckftR-02) indicates moderate impairment and partial support of aquatic life uses, and the percentage above Nevada Creek (BlckftR-03) indicates minor impairment but full support of aquatic life uses.

Other than unusually large percentages of teratological diatoms at the two upstream sites, diatom metrics indicate good to excellent biological integrity and full support of aquatic life uses in the upper Blackfoot River. Diatom diversity, species richness, and the pollution index all increased in a downstream direction, indicating a decrease in organic loading and heavy metals concentrations. Except for small increases in the siltation index, the diatoms indicate that biological integrity improved from upstream to downstream in the upper Blackfoot. Adjacent sites in the upper Blackfoot River had about $40 \%$ of their diatom floras in common (Table 6), indicating that moderate environmental change (recovery) occurred between them.

Poorman Creek. The upper two sites on Poorman Creek also 
had an elevated number of teratological diatom valves, but the percentages here were much smaller than they were at the upper two sites on the Blackfoot River (Table 6). These resulted in ratings of moderate impairment and fair biological integrity at PoorC-01 and PoorC-02. This impairment is probably due to elevated concentrations of heavy metals. Otherwise, diatom metrics indicated only minor impairment and full support of aquatic life uses in Poorman Creek.

Diatom diversity and species richness in Poorman Creek increased in a downstream direction, perhaps in response to a decline in concentrations of heavy metals. Slowing current velocities and warmer water temperatures may also contribute to an increase in diatom diversity. A slightly elevated siltation index indicates minor impairment from sedimentation at poorC-02 (Table 6).

Most of the major diatom species in Poorman Creek are sensitive to pollution (Table 6). Pollution index values for Poorman Creek were relatively low for a mountain stream and were about the same at all three sites. The one major species present that is somewhat tolerant of organic enrichment--Synedra ulna-was most abundant at the upstream site (PoorC-01). In Table 6, the similarity index indicates a much greater floristic change occurred between the upper and middle sites (26\% similar floras) than between the middle and lower sites (52\% similar floras).

Arastra Creek. The upper site on Arrastra Creek had a high percentage of abnormal diatom valves (3.67\%) that indicates moderate impairment and partial support of aquatic life uses (Table 7). As with Poorman Creek and the upper Blackfoot River, this impairment was likely due to elevated concentrations of heavy metals. The percentage of teratological diatom valves dropped to an acceptable level at AraC-02. 
Diatom species diversity and species richness also declined from AraC-01 to AraC-02 (Table 7). This decline in diversity was due mainly to an abundance of Hannaea arcus at AraC-02. This diatom and Hydrurus foetidus, which dominated the periphyton at this site, both indicate cold waters of high quality. Hence the low diatom diversity and species richness values at this site are likely due to natural stressors, such as cold water temperatures, low concentrations of dissolved solids, and moderate current velocities.

Sandbar Creek. Both sites on Sandbar Creek had elevated percentages of abnormal diatoms (Table 7). The percentage at SbrC-01 ( $3.71 \%$ ) indicated moderate impairment and partial support of aquatic life uses; the percentage at SbrC-02 (10.26) indicated severe impairment and nonsupport of aquatic life uses.

In addition, both sites on Sandbar Creek had depressed diatom diversity and species richness values, indicating moderate to severe stress (Table 7). Diatoma mesodon, the dominant diatom species at the upstream site, is a cold water stenotherm (Lowe 1974). I have recorded large numbers of this species in mine adit discharges and in streams that receive mine adit discharges (unpublished data). It appears to be a good indicator of stream sites that are fed primarily by groundwater.

The dominant diatom species at the downstream site (SbrC-02) was Achnanthidium minutissimum (synonym: Achnanthes minutissima) (Table 7). This is a pioneer species which, when present in very large numbers, indicates some form of chemical, physical or biological disturbance (Barbour et al. 1999). Although diatom associations in unpolluted streams in Montana may be composed of up to 70\% Achnanthidium minutissimum, much larger percentages of this diatom almost always occur in streams that receive mining wastes (unpublished data). The large percentage of this diatom 
(86.5\%) at SbrC-02 and the resulting low diversity index (0.96) both indicate severe impairment and nonsupport of uses.

The two sites on Sandbar Creek shared only about a quarter of their diatom floras (Table 7). This indicates that a moderate amount of environmental change (impairment) occurred between the two sites.

Willow Creek. Willow Creek was the only one of the study streams where diatoms indicated that both sites suffered only minor impairment and fully supported their aquatic life uses (Table 7). The upstream site (WilC-01) had a slightly elevated siltation index and a few abnormal diatom valves. The lower site (WilC-02) had somewhat depressed pollution index, indicating some organic loading. This organic loading may be natural and due to the swampy nature of this stream.

Both sites supported relatively large numbers of small, free-living Fragilariaceae (Fragilaria vaucheriae, Staurosira construens, Synedra rumpens) (Table 7). These diatoms indicate highly stable stream flows and reflect the low gradient and stable flows of Willow Creek. The two sites on Willow Creek had almost half of their diatom floras in common, indicating only minor environmental change occurred between them.

Both sites on willow Creek supported a few abnormal diatom valves (Table 7) but these sites had two of the three lowest percentages of abnormal valves of all the sites in the study area (Figure 1). The upper Blackfoot River and the tributaries sampled for this study are unusual in that abnormal valves were recorded at all study sites (Figure 1). This probably indicates the influence of elevated heavy metals in these waters. 


\section{LITERATURE CITED}

APHA. 1998. Standard Methods for the Examination of Water and Wastewater. 20th Edition. American Public Health Association, Washington, D.C.

Bahls, L.L. 1979. Benthic diatom diversity as a measure of water quality. Proc. Mont. Acad. Sci. 38:1-6.

Bahls, L.L. 1993. Periphyton Bioassessment Methods for Montana Streams (Revised). Montana Department of Health and Environmental Sciences, Helena.

Bahls, L.L. 1998. Biotic Integrity of Upper Tenmile Creek Based on Periphyton Community Structure and Composition. Prepared for the Lewis and Clark County Water Quality Protection District, Helena, Montana.

Bahls, L.L. 2001. Support of Aquatic Life Uses in Selected Tributaries of the Big Hole River Based on the Composition and Structure of the Benthic Algae Community. Prepared for the state of Montana Department of Environmental Quality, Monitoring and Data Management Bureau, Helena, Montana.

Bahls, L.L., Bob Bukantis, and Steve Tralles. 1992. Benchmark Biology of Montana Reference Streams. Montana Department of Health and Environmental Sciences, Helena.

Bahls, L.L., and E.E. Weber. 1988. Ecology and distribution in Montana of Epithemia sorex Kutz., a common nitrogen-fixing diatom. Proc. Mont. Acad. Sci. 48:15-20.

Barbour, M.T., J. Gerritsen, B.D. Snyder, and J:B. Stribling. 1999. Rapid Bioassessment Protocols for Use in Streams and Wadeable Rivers: Periphyton, Benthic Macroinvertebrates and Fish. Second Edition. EPA/841-B-99-002. U.S. EPA, Office of Water, Washington, D.C.

Dillard, G.E. 1999. Common Freshwater Algae of the United states. J. Cramer, Berlin.

Johansen, J.R. 1999. Diatoms of Aerial Habitats. Chapter 12 in Stoermer, E.F., and J.P. Smol (eds.), The Diatoms, Cambridge University Press, New York.

Karr, J.R., and D.R. Dudley. 1981. Ecological perspectives on water quality goals. Environmental Management 5:55-69.

Krammer, K., and H. Lange-Bertalot. 1986. Bacillariophyceae, Part 2, Volume 1: Naviculaceae. In Ettl, H., J. Gerloff, H. Heynig, and D. Mollenhauer (eds.), Freshwater Flora of Middle Europe. Gustav Fischer Publisher, New York. 
Krammer, K., and H. Lange-Bertalot. 1988. Bacillariophyceae, Part 2, Volume 2: Bacillariaceae, Epithemiaceae, Surirellaceae. In Ettl, H., J. Gerloff, H. Heynig, and D. Mollenhauer (eds.), Freshwater Flora of Middle Europe. Gustav Fischer Publisher, New York.

Krammer, K., and H. Lange-Bertalot. 1991a. Bacillariophyceae, Part 2, Volume 3: Centrales, Fragilariaceae, Eunotiaceae. In Ettl, H., J. Gerloff, H. Heynig, and D. Mollenhauer (eds.), Freshwater Flora of Middle Europe. Gustav Fischer Publisher, stuttgart.

Krammer, K., and H. Lange-Bertalot. 1991b. Bacillariophyceae, Part 2, Volume 4: Achnanthaceae, Critical Supplement to Navicula (Lineolatae) and Gomphonema, Complete List of Literature for Volumes 1-4. In Ettl, H., G. Gartner, J. Gerloff, H. Heynig, and D. Mollenhauer (eds.), Freshwater Flora of Middle Europe. Gustav Fischer Publisher, stuttgart.

Lange-Bertalot, Horst. 1979. Pollution tolerance of diatoms as a criterion for water quality estimation. Nova Hedwigia $64: 285-304$.

Lowe, R.L. 1974. Environmental Requirements and Pollution Tolerance of Freshwater Diatoms. EPA-670/4-74-005.

McFarland, B.H., B.H. Hill, and W.T. Willingham. 1997. Abnormal Fragilaria spp. (Bacillariophyceae) in streams impacted by mine drainage. Jour. of Freshwater Ecology 12(1):141-149.

Palmer, C.M. 1969. A composite rating of algae tolerating organic pollution. Journal of Phycology 5:78-82.

Palmer, C.M. 1977. Algae and Water Pollution: An Illustrated Manual on the Identification, Significance, and Control of Algae in water Supplies and in Polluted water. EPA-600/9-77-036.

Patrick, Ruth, and C.W. Reimer. 1966. The Diatoms of The United States Exclusive of Alaska and Hawaii. Volume 1:

Fragilariaceae, Eunotiaceae, Achnanthaceae, Naviculaceae. Monograph Number 13, The Academy of Natural Sciences, Philadelphia.

Patrick, Ruth, and C.W. Reimer. 1975. The Diatoms of The United States Exclusive of Alaska and Hawaii. Volume 2, Part 1: Entomoneidaceae, Cymbellaceae, Gomphonemaceae, Epithemiaceae. Nonograph Number 13, The Academy of Natural Sciences, Philadelphia.

Plafkin, J.L., M.T. Barbour, K.D. Porter, S.K. Gross, and R.M. Hughes. 1989. Rapid Bioassessment Protocols for Use in 
Rivers and Streams: Benthic Macroinvertebrates and Fish. EPA 440-4-89-001.

Prescott, G.W. 1978. How to know the Freshwater Algae. Third Edition. Wm. C. Brown Company Publishers, Dubuque, Iowa.

Renfro, H.B., and D.E. Feray. 1972. Geological Highway Map of the Northern Rocky Mountain Region. American Association of Petroleum Geologists, Tulsa, Oklahoma.

Smith, G.M. 1950. the Fresh-water Algae of The United States. McGraw-Hill Book Company, New York.

Stevenson, R.J., and L.L. Bahls. 1999. Periphyton Protocols. Chapter 6 in Barbour, M.T., J. Gerritsen, B.D. Snyder, and J.B. Stribling. Rapid Bioassessment Protocols for Use in Streams and Wadeable Rivers: Periphyton, Benthic Macroinvertebrates and Fish. Second Edition. EPA/841-B-99002. U.S. EPA, Office of Water, Washington, D.C.

USDA. 1976. Climax Vegetation of Montana (map). U. S. Department of Agriculture, Soil Conservation Service, Cartographic Unit, Portland.

Whitford, L.A., and G.J. Schumacher. 1984. A Manual of FreshWater Algae (Revised). Sparks Press, Raleigh, North Carolina.

Whittaker, R.H. 1952. A study of summer foliage insect communities in the Great Smoky Mountains. Ecological Monographs $22: 1-44$.

Woods, A.J., Omernik, J.M., Nesser, J.A., Shelden, J., and Azevedo, S.H. 1999. Ecoregions of Montana (color poster with map), U.S. Geological Survey, Reston, Virginia. 


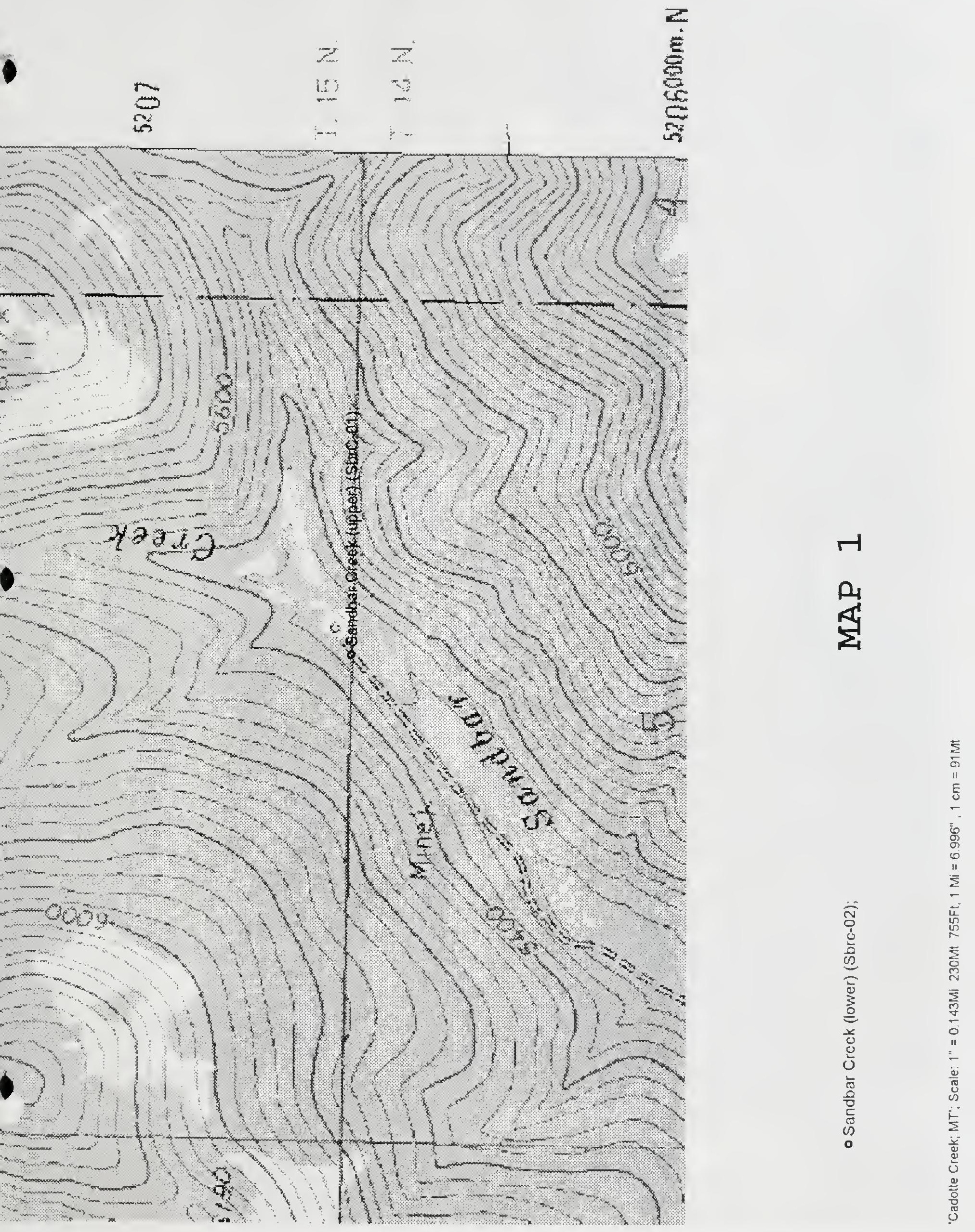




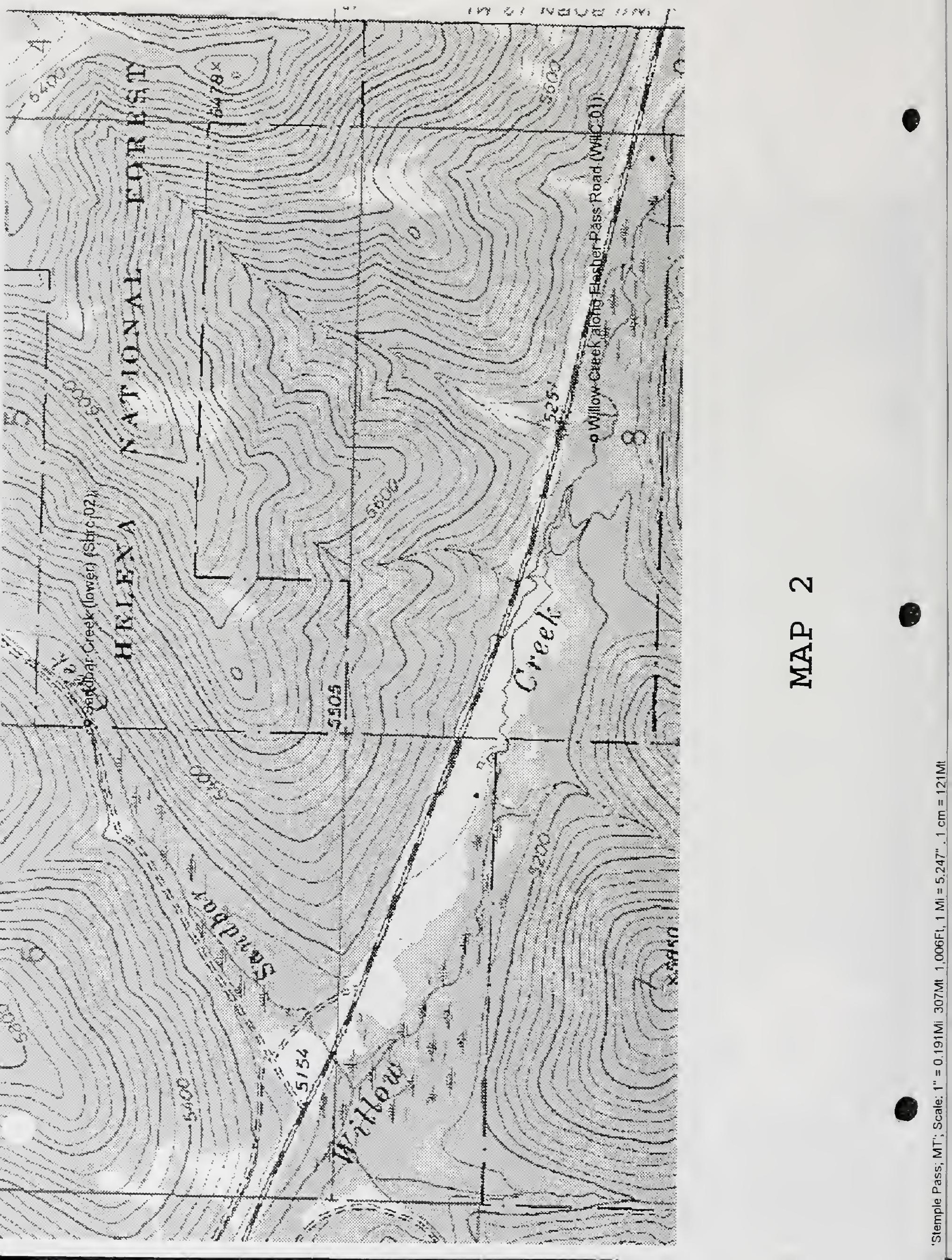




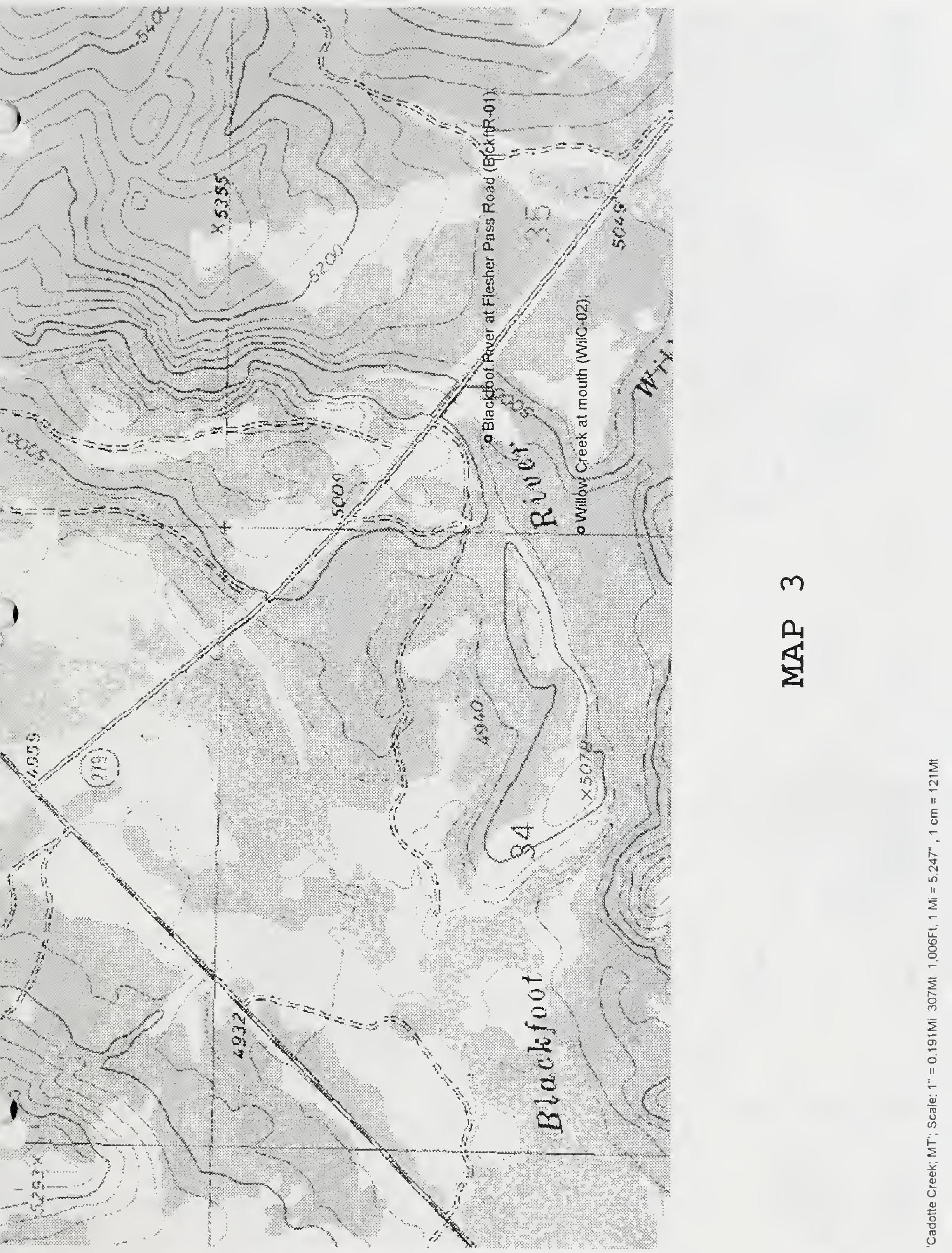




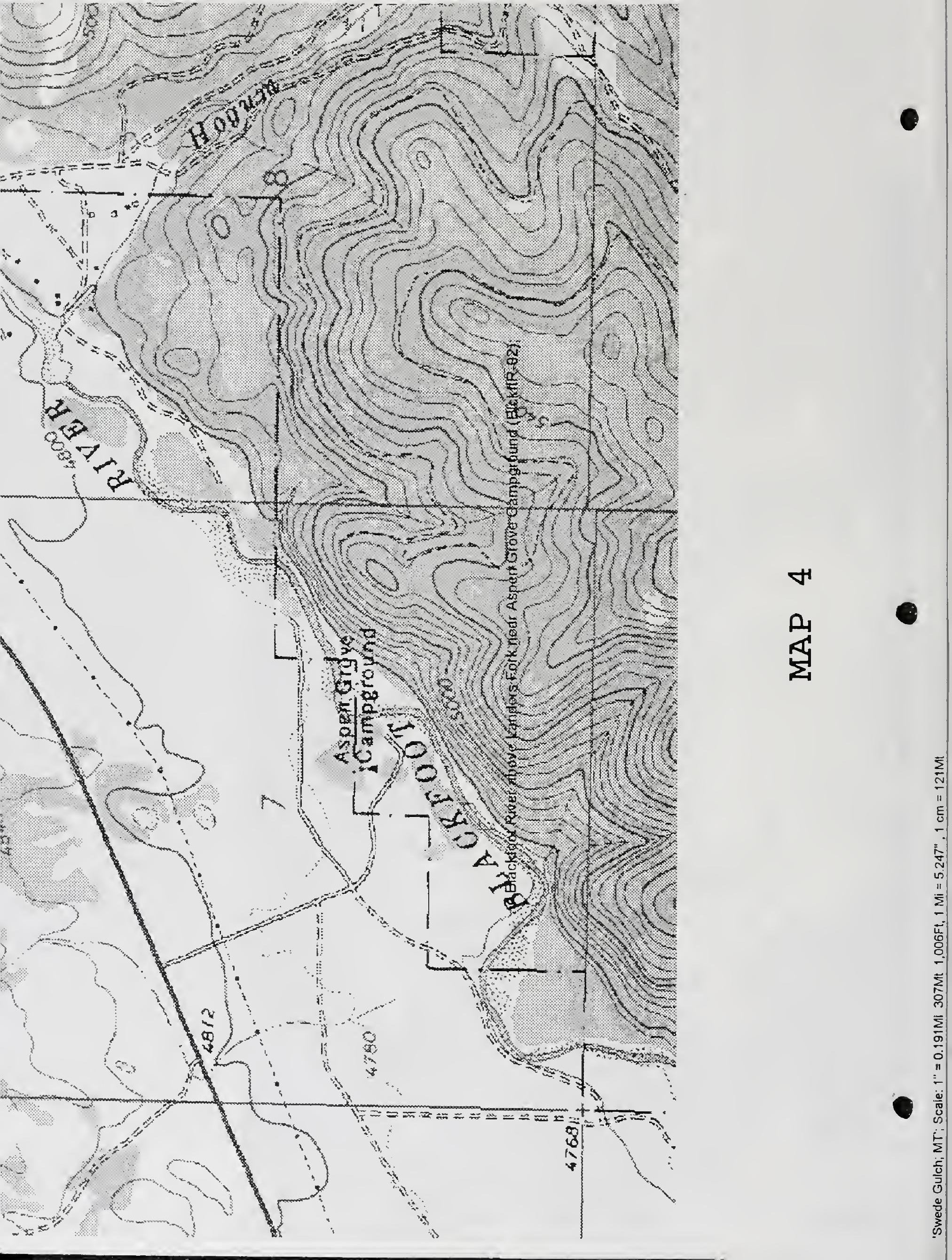






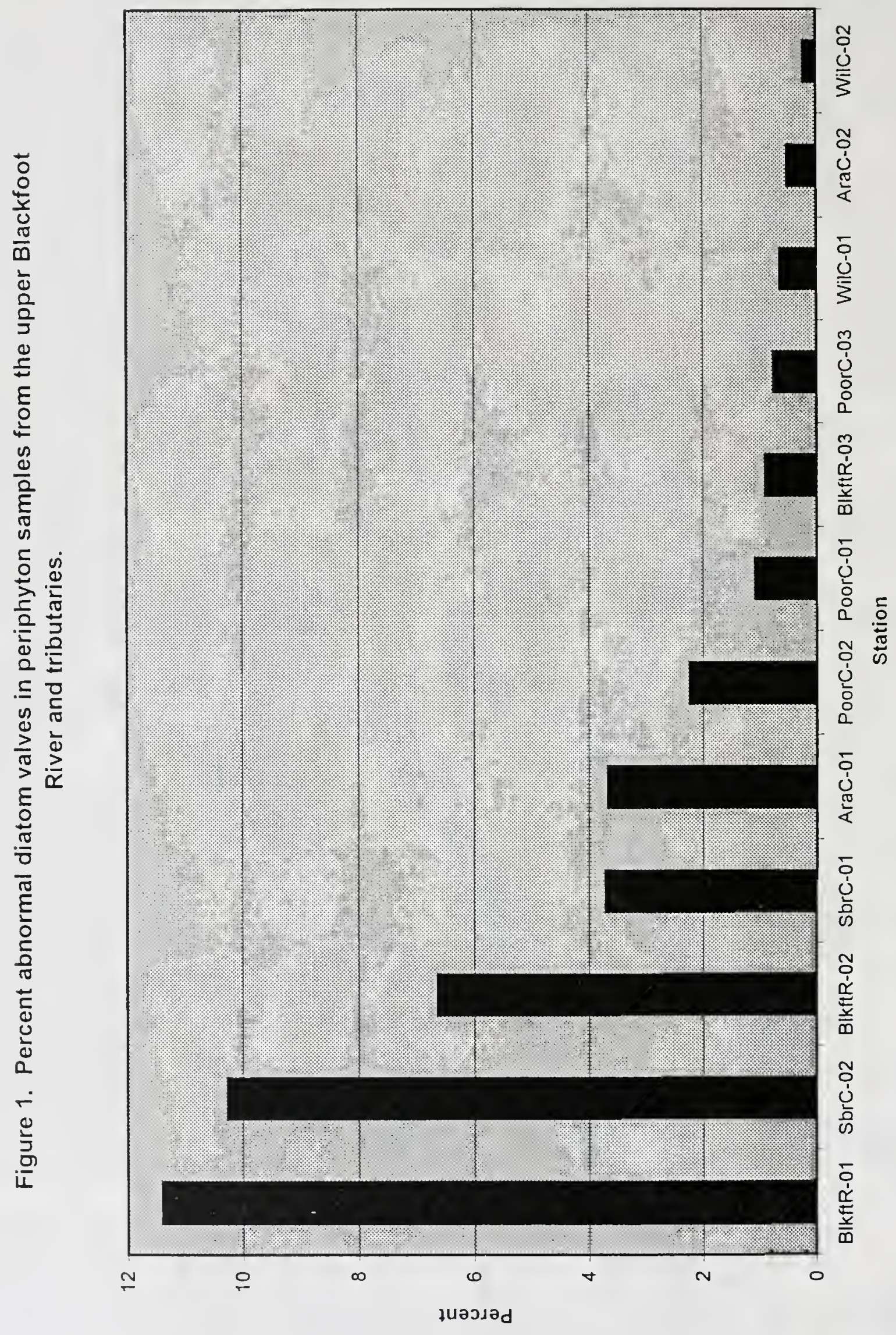

- 


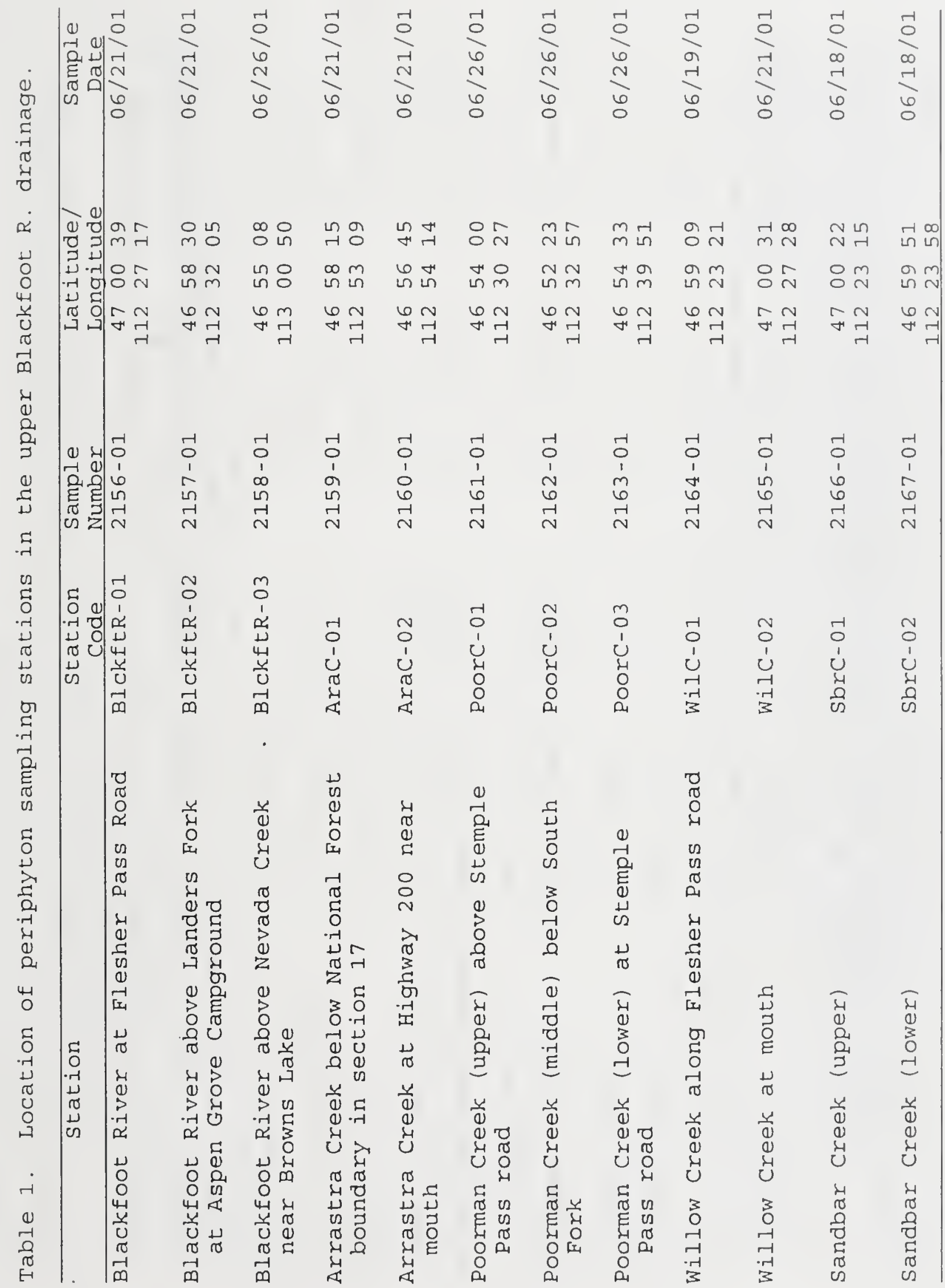




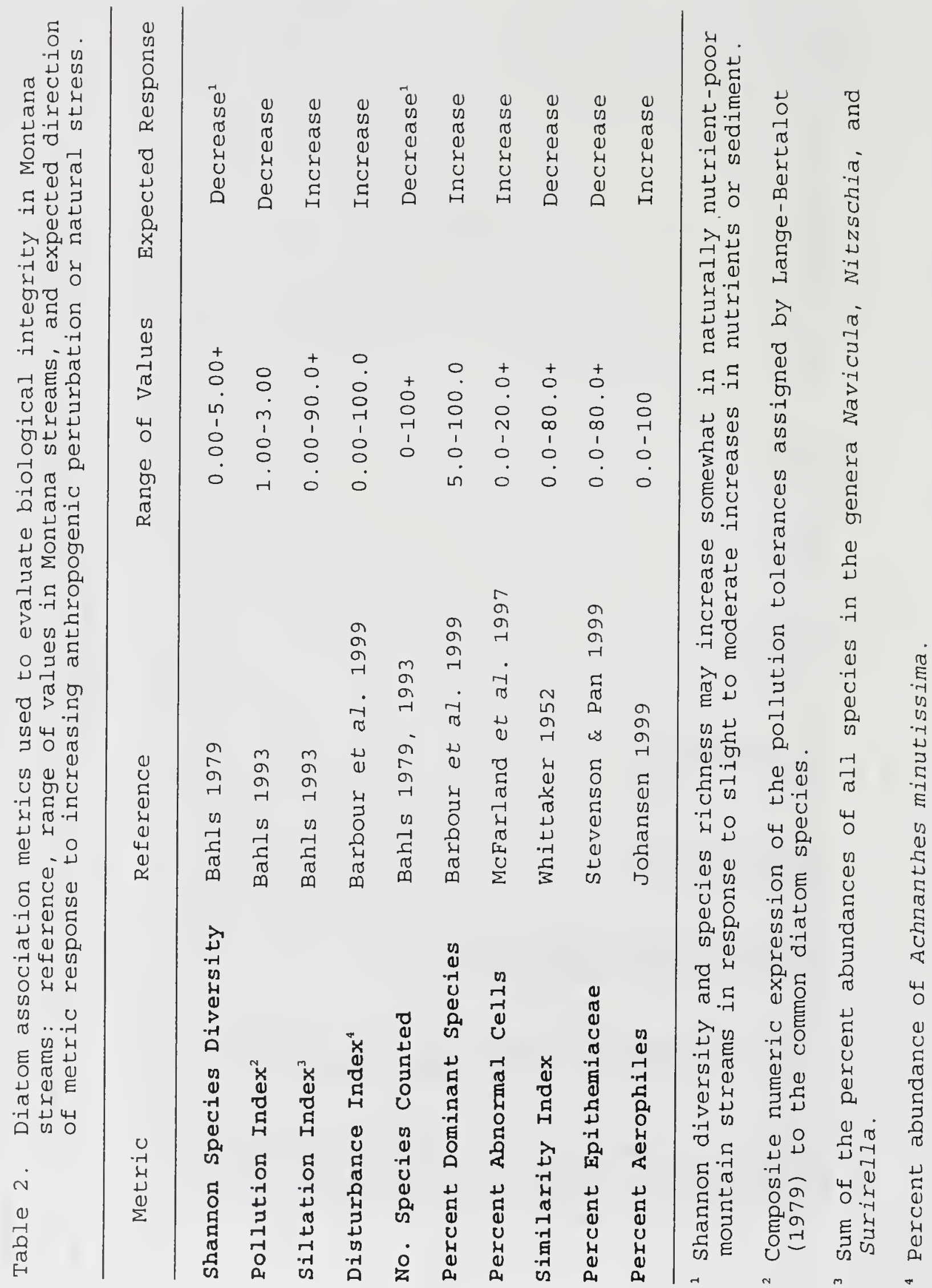




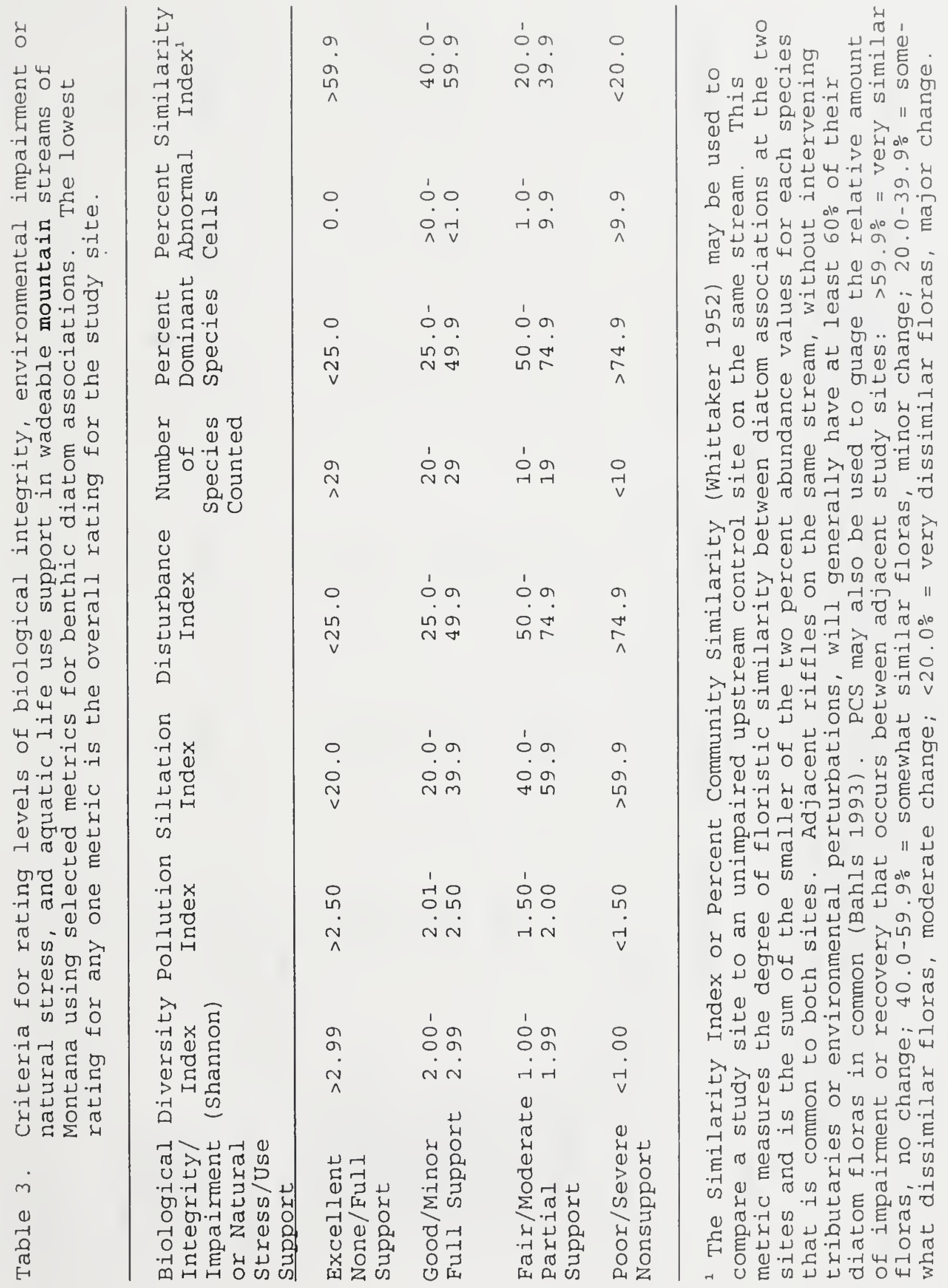




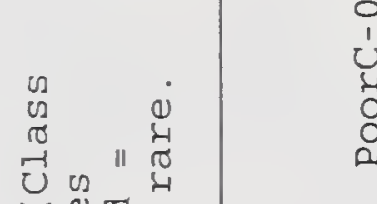

-1

है है.. फ

익

r 0 -

ช్

म

फ त्र.न

- द्व

Q.

हैप्रण

न1

只 E I

О. .

.-1 \& है. ‥

ब

ลन

ॠ

Б䒕

$\rightarrow \perp$ I

$\rightarrow-\pi)$

ने न

चा.न.

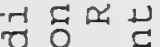

4 다

○一

ชᄄ山 엉

要

(1)

जब $10-1$ ॥

대

(1) क्र

Ч

崩䒕骂

(1) - 0 要

บิิ

एक $\frac{0}{0}$

O $\cup$

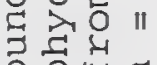

त्रूण

开

$>\pi \Delta$

त- 0 U

म $\rightarrow$ U

๘०न-

거들

只 ๓

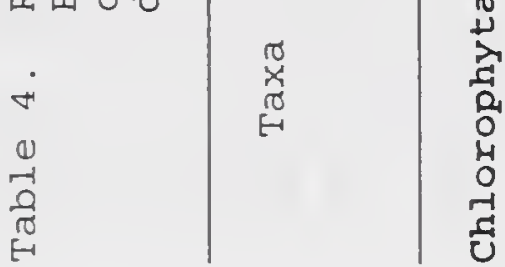

$N$
0
1
$\frac{1}{4}$
4
$\frac{4}{U}$
$\frac{1}{01}$

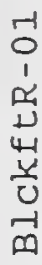

$\sum_{H}^{\text {Ln }} \quad \frac{m}{0} \frac{N}{0}$

$\sum_{4-1}^{-1} \quad \frac{6}{0}$

$\frac{1}{\pi}$

$\frac{6}{0}$

$\frac{0}{\pi}$

స్

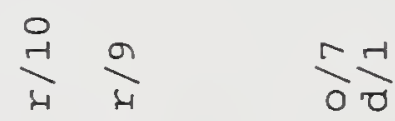

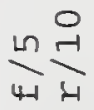

$\overbrace{0}^{-1}$

$\sum_{0}^{m} \quad \frac{6}{0}$

$\varliminf_{0}^{\infty}$

$\sum_{4-1}^{N} \frac{6}{0}$

$\frac{1}{0}$

$$
\text { (n) }
$$

8

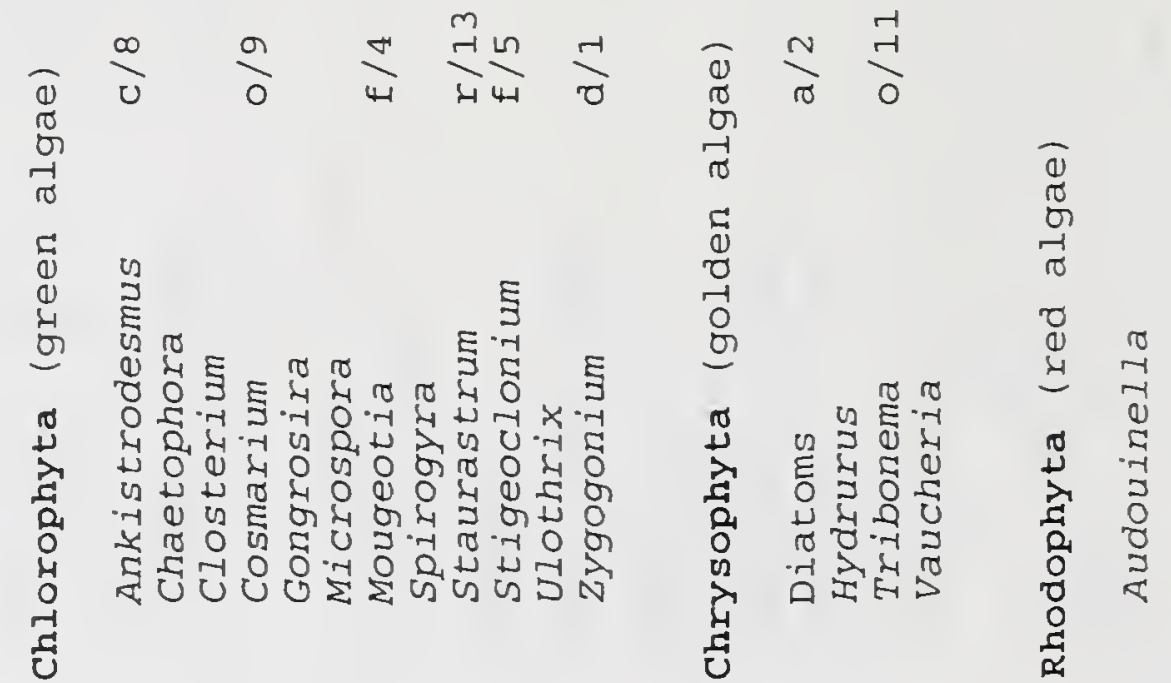




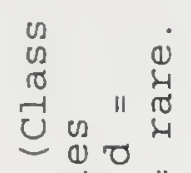

() त् त्र

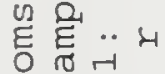

$\begin{array}{llll}0 & \sigma & 0 \\ + & 0 & 0\end{array}$

-

प्र 2

- मेन्न म

岳

(1) न्त ए

E

ब

$>$ I E

ठ. न ह

त ब ह ह .

त 0 E

入 0100

बत

등

\%

$4+11$

$\pi$
-1

ते 0

द 1 .

- 5 도

엄ㅇ

4 0 ว

0040

ज 0 ए

40

a 0 1) 1

त्नल

(1) का 4

(1) को

$\nabla \Omega$

४

४ - 4 号

บ 0 号

\% 0 \%

$\checkmark \cup E$

$\exists>0$ II

อ.

00.

(1) म 4

$>\sigma \perp$

त

丩

ס न न न न

Н U न

瓜 $U$

نे

(1)

กิ

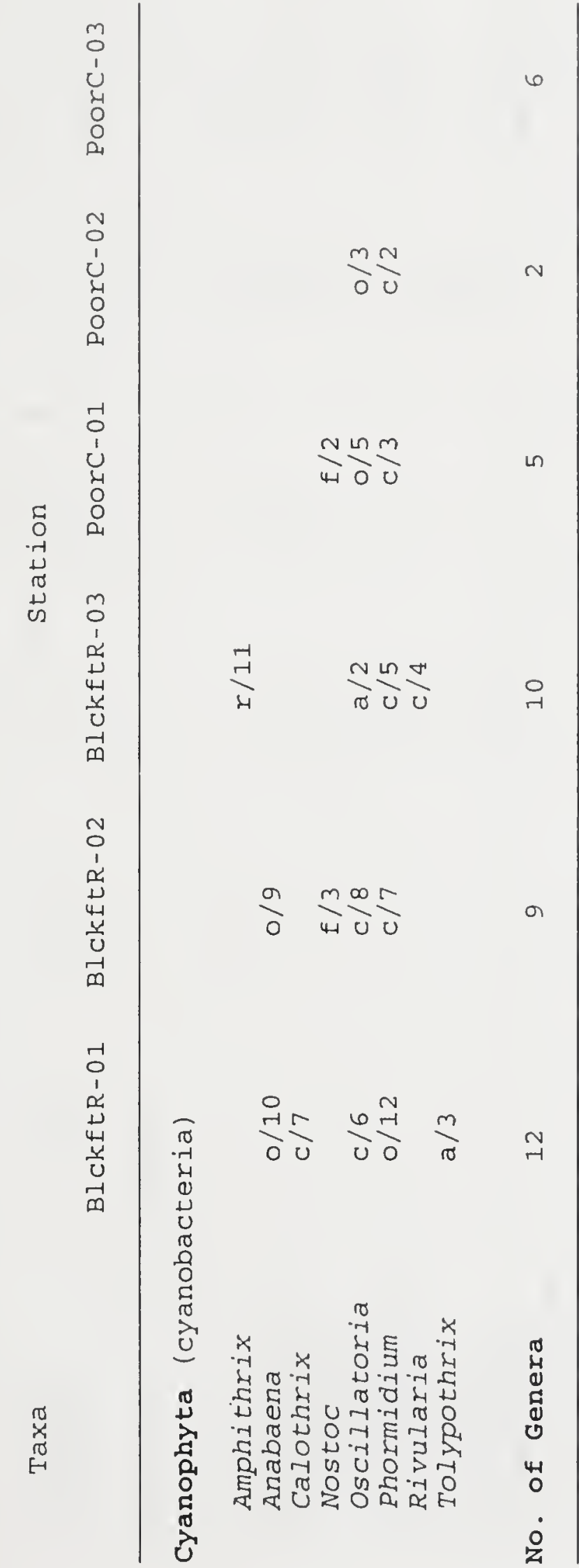




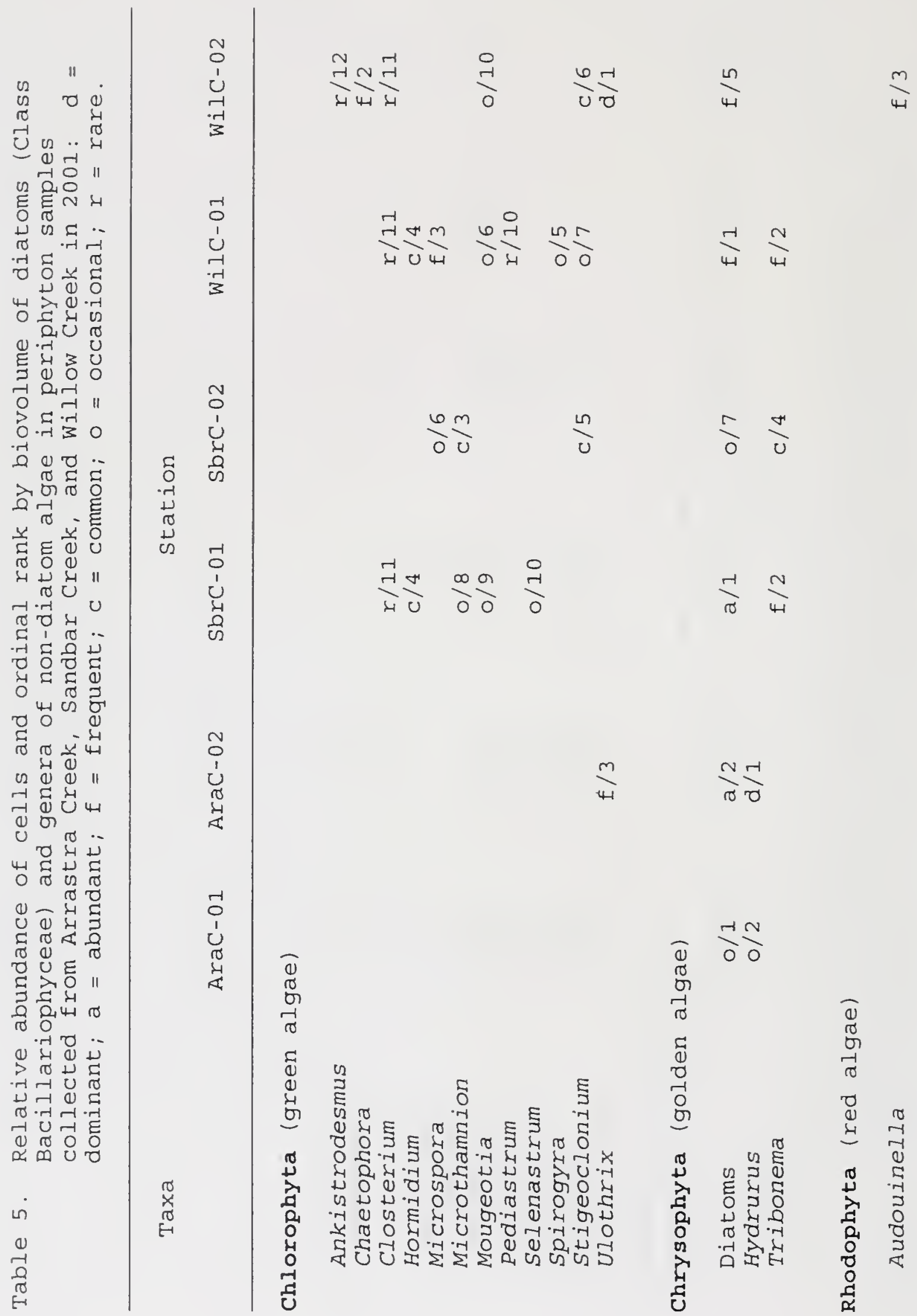




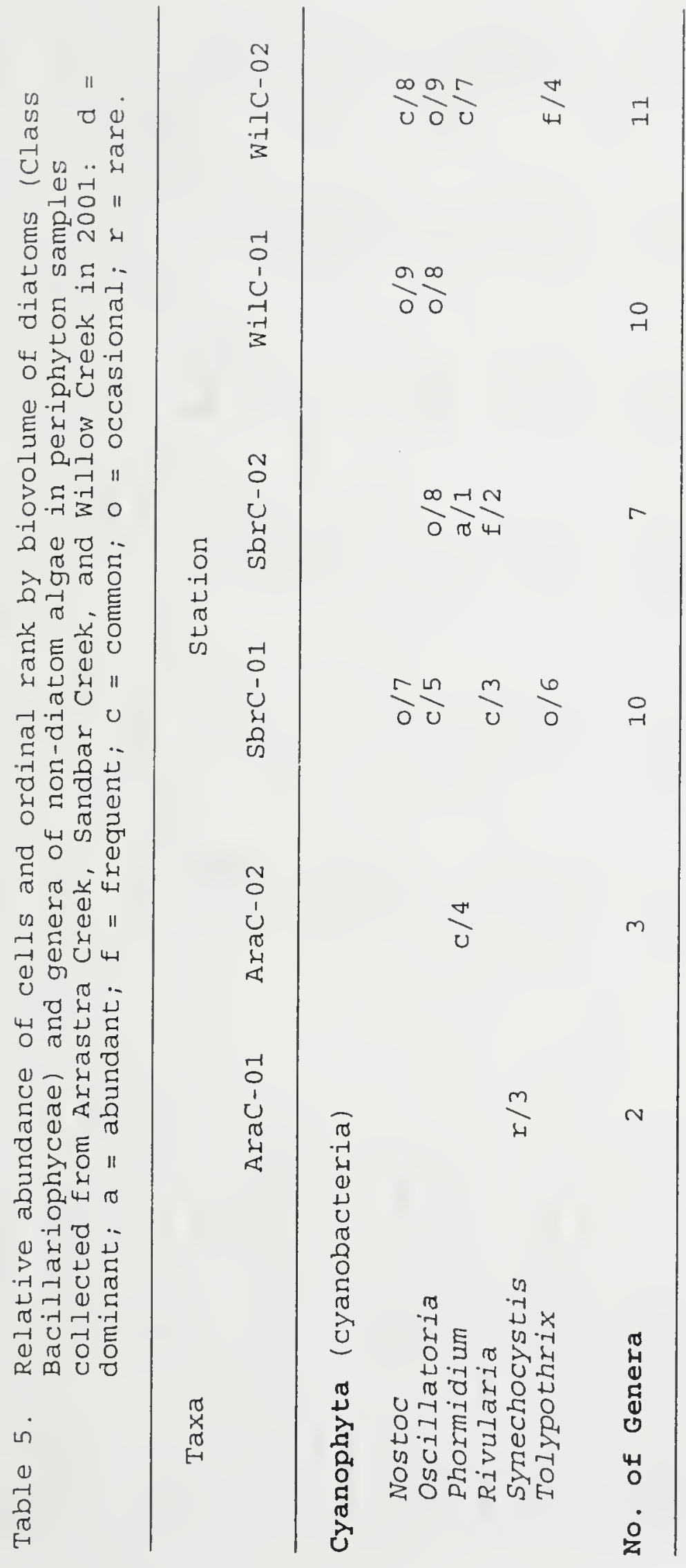




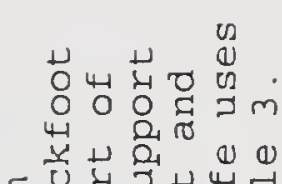
हु \pm ल ब क ज ब

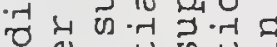

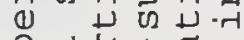
- भिन म्र 10 (1) भित पै स (1) थ थ म 돈 U山 (n) $E$ E U U य ०.न वृ म्न ह 0 मे व व 0 .न

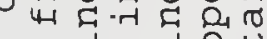
(1) ठ क न ब्न है (1) था \& जा पर न 3 (1) न1

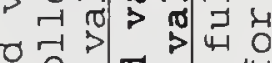

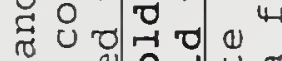

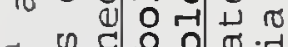

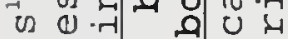
(1) न1 $\because-7$ व บ है थै (1) ซ

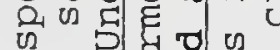
द्न न ब थ 0 ह0 0 .

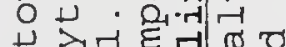
ब द्व० - 00 a ठ

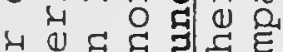
0 लिन्न म

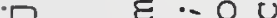
है

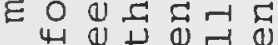

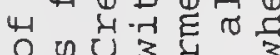

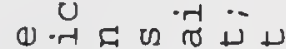
U हD ह थ है तथ द्र Ј.त ह ह 잉 0 (1)

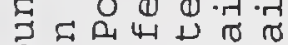

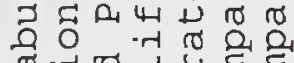
চ-न ग्न म ב. (1) U म हH บ 0 (1) (1) था.त क्त म

6

है

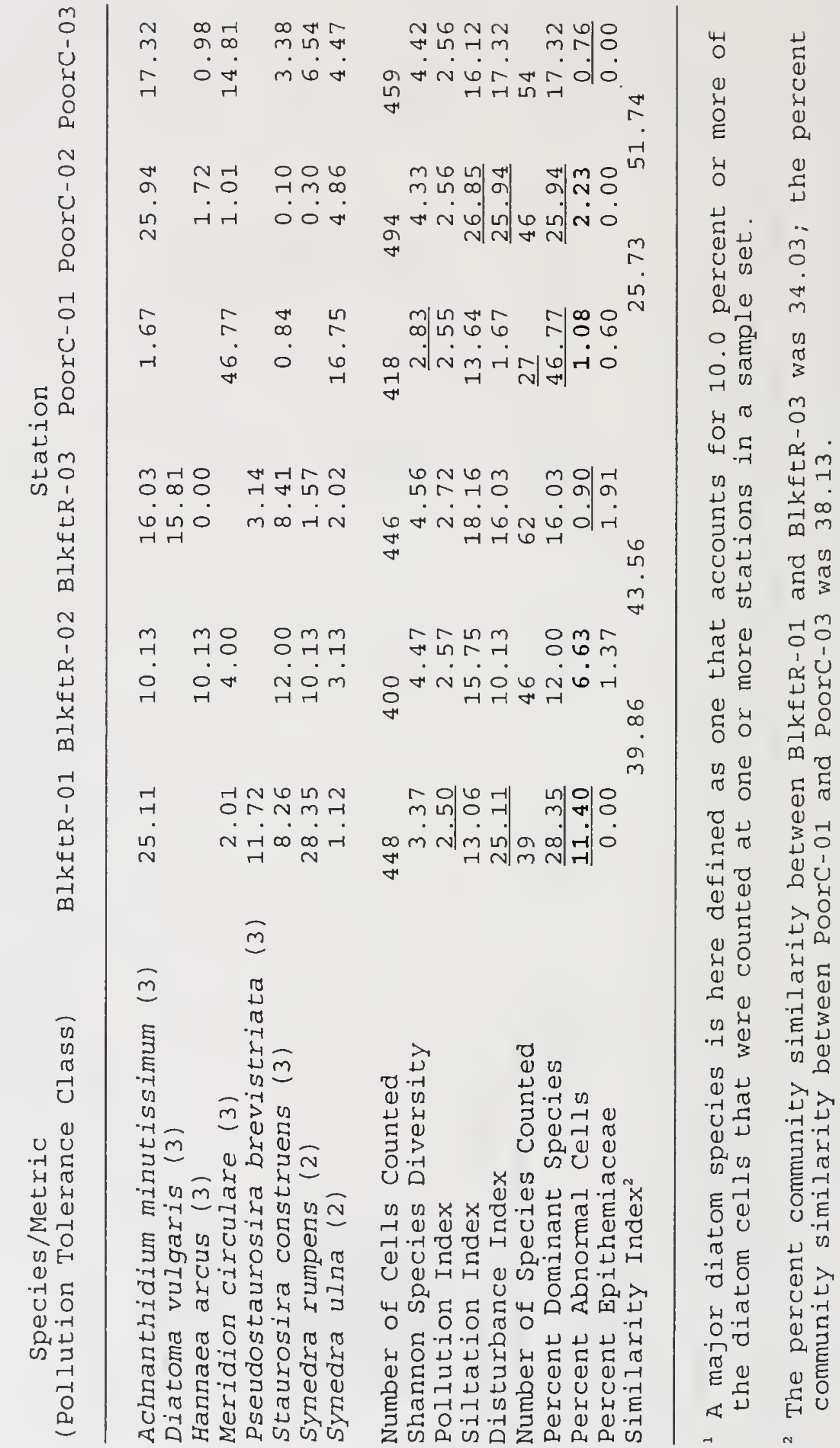




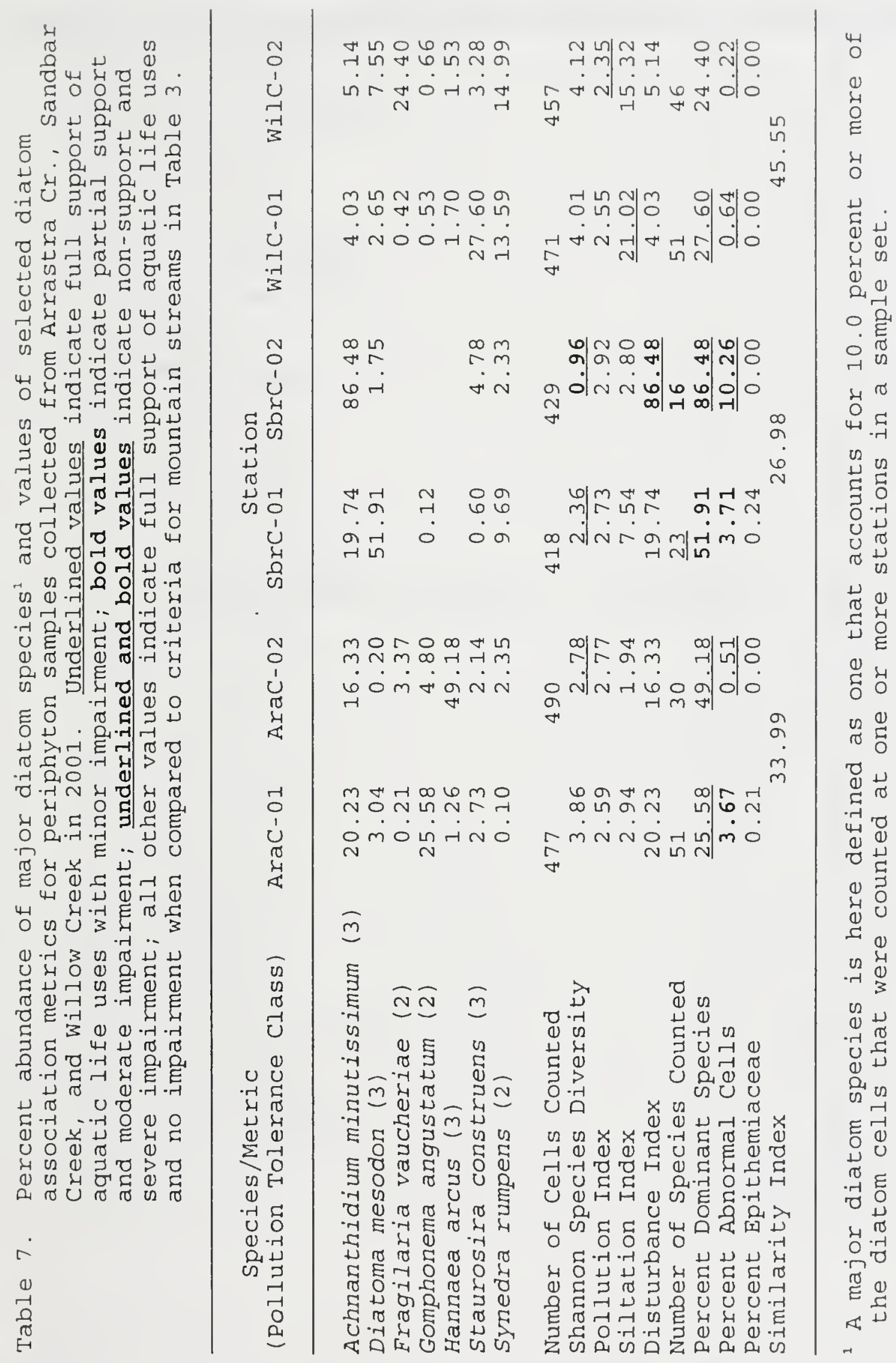


APPENDIX A: DIATOM PROPORTIONAL COUNTS 


\begin{tabular}{|c|c|c|c|}
\hline Genus/Species Variety & Pollution Folerance Class & Count & Percent \\
\hline 215601 Achnanthes lanceolata & 2 & 2. & 0.22 \\
\hline 215601 Achnanthidium affine & 3 & 2 & 0.22 \\
\hline 215601 Achnanthidium biasolettianum & 3 & 0. & 0.00 \\
\hline 215601 Achnanthidium minutissimum & 3 & 225 & 25.11 \\
\hline 215601 Amphipleura pellucida & 2 & 0 & 0.00 \\
\hline 215601 Aulacoseira italica & 3 & 3 & 0.33 \\
\hline 215601 Aulacoseira lirata & 3 & 13 & 1.45 \\
\hline 215601 Caloneis bacillum & 2 & 20 & 2.23 \\
\hline 215601 Caloneis tenuis & 3 & 2 & 0.22 \\
\hline 215601 Cavinula cocconeiformis & 3 & 4 & 0.45 \\
\hline 215601 Cavinula pseudoscutiformis & 3. & 0 & 0.00 \\
\hline 215601 Cyclotella meneghiniana & 2 & 1 & 0.11 \\
\hline 215601 Cymbella sp. & 3. & 2. & 0.22 \\
\hline 215601 Diatoma mesodon & 3 & 12 & 1.34 \\
\hline 215601 Diatoma tenue & 2. & 0 & 0.00 \\
\hline 215601Encyonema minutum & 2 & 2 & 0.22 \\
\hline 215601 Epithemia adnata & 2 & 0 & 0.00 \\
\hline 215601 Epithemia sorex & 3 & 0 & 0.00 \\
\hline 215601 Fragilaria_capucina & 2 & 10. & 1.12 \\
\hline 215601. Fragilaria crotonensis & 3 & 9 & 1.00 \\
\hline 215601 Fragilaria robusta & 3 & 0 & 0.00 \\
\hline 215601 Eragilaria vaucheriae & 2 & 2 & 0.22 \\
\hline 215601.Gomphonema clavatum & 2 & 2 & 0.22 \\
\hline 215601 Gomphonema intricatum & 3 & 2 & 0.22 \\
\hline 215601 Gomphonema minutum. & 3 & 1 & 0.11 \\
\hline 215601 Meridion circulare & 3 & 18 & 2.01 \\
\hline 215601 Navicula arvensis & 1 & 17 & 1.90 \\
\hline 215601 Navicula cryptocephala & 3 & 2 & 0.22 \\
\hline 215601 Navicula detenta & 3 & 0 & 0.00 \\
\hline 215601 Navicula elginensis & 3 & 2 & 0.22 \\
\hline 215601 Navicula medioconvexa & 3 & 6 & 0.67 \\
\hline 215601Navicula_minima & 1 & 33 & 3.68 \\
\hline 215601 Nitzschia acicularis & 2 & 1 & 0.11 \\
\hline 215601 Nitzschia capitellata & 2 & 0 & 0.00 \\
\hline 215601 Nitzschia communis & 1 & 0 & 0.00 \\
\hline 215601 Nitzschia flexa & 2 & 2 & 0.22 \\
\hline 215601 Nitzschia fonticola & 3 & 9 & 1.00 \\
\hline 215601. Nitzschia frustulum & 2 & 2 & 0.22 \\
\hline 215601 Nitzschia gracilis & 2 & 0 & 0.00 \\
\hline 215601 Nitzschia linearis & 2 & 2 & 0.22 \\
\hline 215601 Nitzschia palea & 1 & 4 & 0.45 \\
\hline 215601 Nitzschia perminuta & 3 & 6 & 0.67 \\
\hline 215601 Nitzschia pumila & 2 & 4 & 0.45 \\
\hline 215601 Nitzschia pura & 2 & 22 & 2.46 \\
\hline 215601 Pseudostaurosira brevistriata & 3 & 105 & 11.72 \\
\hline 215601, Rhopalodia gibba & 2 & 0 & 0.00 \\
\hline 215601 Sellaphora pupula & 2 & 0 & 0.00 \\
\hline 215601 Staurosira construens & 3 & 74 & 8.26 \\
\hline 215601 Staurosirella leptostauron & 3 & 0 & 0.00 \\
\hline 215601 Staurosirella pinnata & 3 & 8 & 0.89 \\
\hline 215601 Surirella sp. & 2 & 1 & 0.11 \\
\hline 215601 Synedra rumpens & 2 & 254 & 28.35 \\
\hline 215601 Synedra ulna & -1 & 10 & 1.12 \\
\hline
\end{tabular}




\begin{tabular}{|c|c|c|c|}
\hline Genus/Speciest Variety & Pollution Tolerance Class & Count & Percent \\
\hline 215701 Achnanthes lanceolata. & 2 & 10 & 1.25 \\
\hline 215701Achnanthidium biasolettianum & 3 & 2 & 0.25 \\
\hline 215701 Achnanthidium minutissimum & 3 & 81 & 10.13 \\
\hline 215701 Amphipleura pellucida & 2 & 0 & 0.00 \\
\hline 215701 Amphora pediculus & 3 & 0 & 0.00 \\
\hline 215701Aulacoseira distans & 3 & 6 & 0.75 \\
\hline 215701 Aulacoseira italica. & 3 & 1 & 0.13 \\
\hline 215701 Caloneis silicula & 2. & 2 & 0.25 \\
\hline 215701 Cocconeis placentula & 3. & 8 & 1.00 \\
\hline 215701 Cyclotella meneghiniana & 2 & 0 & 0.00 \\
\hline 215701 Cymbella sp. & 3 & 4 & 0.50 \\
\hline 215701 Diatoma mesodon & 3 & 6 & 0.75 \\
\hline 215701 Encyonema auerswaldii & 2 & 4 & 0.50 \\
\hline 215701Encyonema minutum & 2 & 13 & 1.63 \\
\hline 215701 Encyonema silesiacum & 2 & 43 & 5.38 \\
\hline 215701Epithemia sorex & 3 & 4 & 0.50 \\
\hline 215701Epithemia turgida & 3 & 6 & 0.75 \\
\hline 215701Fragilaria_capucina & 2 & 10 & 1.25 \\
\hline 215701 Fragilaria vaucheriae & 2 & 22 & 2.75 \\
\hline 215701. Fragilaniforma bicapitata & 3 & 2 & 0.25 \\
\hline 215701 Gomphoneis eriense & 3 & 0 & 0.00 \\
\hline 215701 Gomphonema acuminatum & 3 & 2 & 0.25 \\
\hline 215701 Gomphonema angustatum & 2 & 2 & 0.25 \\
\hline 215701 Gomphonema kobayasii & 3 & 2 & 0.25 \\
\hline 215701 Gomphonema olivaceoides & 3. & 53 & 6.63 \\
\hline 215701 Gomphonema parvulum & 1. & 2 & 0.25 \\
\hline 215701:Hannaea arcus & 3 & 81 & 10.13 \\
\hline 215701Hantzschia amphioxys & 2 & 0 & 0.00 \\
\hline 215701 Meridion circulare & 3 & 32 & 4.00 \\
\hline 215701 Navicula arvensis & 1 & 5 & 0.63 \\
\hline 215701 Navicula cryptotenella & 2 & 4 & 0.50 \\
\hline 215701 Navicula minima & 1. & 10 & 1.25 \\
\hline 215701 Navicula minuscula & 1. & 24. & 3.00 \\
\hline 215701 Navicula tripunctata & 3. & 4 & 0.50 \\
\hline 215701 Nitzschia amphibia & 2 & 2 & 0.25 \\
\hline 215701 Nitzschia archibaldii & 2 & 22 & 2.75 \\
\hline 215701 Nitzschia dissipata & 3 & 7 & 0.88 \\
\hline 215701 Nitzschia fonticola & 3. & 33. & 4.13 \\
\hline 215701 Nitzschia linearis & 2 & 1. & 0.13 \\
\hline 215701 Nitzschia palea & 1 & 6 & 0.75 \\
\hline 215701 Nitzschia perminuta & 3. & 0 & 0.00 \\
\hline 215701 Nitzschia pumila & 2 & 2 & 0.25 \\
\hline 215701 Nitzschia pura & 2 & 6 & 0.75 \\
\hline 215701 Nitzschia vermicularis & 2 & 0 & 0.00 \\
\hline 215701 Psammothidium helveticum & 3. & 5 & 0.63 \\
\hline 215701 Reimeria sinuata. & 3. & 1. & 0.13 \\
\hline 215701Rhoicosphenia curvata & 3. & 2 & 0.25 \\
\hline 215701Rhopalodia gibba & 2 & 1 & 0.13 \\
\hline 215701Staurosira construens & 3 & 96 & 12.00 \\
\hline 215701 Staurosirella leptostauron & 3. & 27 & 3.38 \\
\hline 215701 Staurosirella pinnata & 3. & 38 & 4.75 \\
\hline 215701 Synedra rumpens & 2 & 81 & 10.13 \\
\hline 215701 Synedra ulna & 2 & 25 & 3.13 \\
\hline
\end{tabular}




\begin{tabular}{|c|c|c|c|c|}
\hline Sample & Genus/SpeciesNariety & Polliution Tolerance Class & Count & Percent \\
\hline \multicolumn{2}{|c|}{ 215801/Achnanthes lanceolata } & 2 & 5 & 0.56 \\
\hline \multicolumn{2}{|c|}{ 215801 Achnanthidium biasolettianum } & 3 & 2 & 0.22 \\
\hline \multicolumn{2}{|c|}{215801 Achnanthidium minutissimum } & 3 & 143 & 16.03 \\
\hline \multicolumn{2}{|c|}{215801 Amphipleura pellucida } & 2 & 4 & 0.45 \\
\hline \multicolumn{2}{|c|}{215801 Amphora inariensis } & 3 & 2 & 0.22 \\
\hline \multicolumn{2}{|c|}{215801 Amphora pediculus } & 3 & 1. & 0.11 \\
\hline \multicolumn{2}{|c|}{215801 Cocconeis pediculus } & 3 & 1 & 0.11 \\
\hline \multicolumn{2}{|c|}{215801 Cocconeis placentula } & 3 & 14 & 1.57 \\
\hline \multicolumn{2}{|c|}{215801 Cymatopleura solea } & 2 & 0 & 0.00 \\
\hline \multicolumn{2}{|c|}{215801 Cymbella affinis } & 3 & 20 & 2.24 \\
\hline \multicolumn{2}{|c|}{215801 Cymbella subaequalis } & 3 & 0 & 0.00 \\
\hline \multicolumn{2}{|c|}{215801 Denticula Kuetzingii } & 3 & 2 & 0.22 \\
\hline \multicolumn{2}{|c|}{215801 Diatoma mesodon } & 3 & 2 & 0.22 \\
\hline \multicolumn{2}{|c|}{215801 Diatoma moniliformis } & 2 & 6 & 0.67 \\
\hline \multicolumn{2}{|c|}{215801 Diatoma tenue } & 2 & 3 & 0.34 \\
\hline \multicolumn{2}{|c|}{215801 Diatoma vulgaris } & 3 & 141 & 15.81 \\
\hline \multicolumn{2}{|c|}{215801 Encyonema auerswaldii } & 2 & 2 & 0.22 \\
\hline \multicolumn{2}{|c|}{215801 Encyonema minutum } & 2 & 9 & 1.01 \\
\hline \multicolumn{2}{|c|}{215801 Encyonema prostratum } & 3 & 5 & 0.56 \\
\hline \multicolumn{2}{|c|}{215801 Encyonema silesiacum } & 2 & 32 & 3.59 \\
\hline \multicolumn{2}{|c|}{215801 Encyonopsis microcephala } & 2 & 23 & 2.58 \\
\hline \multicolumn{2}{|c|}{215801 Epithemia adnata } & 2 & 1 & 0.11 \\
\hline \multicolumn{2}{|c|}{ 215801 Epithemia sorex } & 3 & 10 & 1.12 \\
\hline 21580 & Epithemia turgida & 3 & 0 & 0.00 \\
\hline 21580 & Fragilaria capucina & 2 & 4 & 0.45 \\
\hline 21580 & Fragilaria vaucheriae & 2 & 28 & 3.14 \\
\hline 21580 & Gomphoneis herculeana & 3 & 2 & 0.22 \\
\hline 21580 & Gomphonema clavatum & 2 & 4 & 0.45 \\
\hline 21580 & Gomphonema kobayasii & 3 & 2 & 0.22 \\
\hline 21580 & Gomphonema olivaceum & 3 & 6 & 0.67 \\
\hline 21580 & Gomphonema parvulum & 1 & 1 & 0.11 \\
\hline 21580 & Gomphonema sarcophagus & 2 & 2. & 0.22 \\
\hline 21580 & Gomphonema septata & 3 & 2 & 0.22 \\
\hline 21580 & Hannaea arcus & 3 & 0 & 0.00 \\
\hline 21580 & Hantzschia amphioxys & 2 & 0 & 0.00 \\
\hline 21580 & Melosira varians & 2 & 13 & 1.46 \\
\hline 21580 & Navicula capitatoradiata & 2 & 10 & 1.12 \\
\hline 21580 & Navicula cryptotenella & 2 & 23 & 2.58 \\
\hline 21580 & Navicula menisculus & 2 & 1 & 0.11 \\
\hline 21580 & Navicula radiosa & 3 & 4 & 0.45 \\
\hline 21580 & Navicula reichardtiana & 2 & 11. & 1.23 \\
\hline 21580 & Navicula sp. & 2 & 2 & 0.22 \\
\hline 21580 & Navicula tripunctata & 3 & 13 & 1.46 \\
\hline 21580 & Nitzschia angustata & 2 & 2 & 0.22 \\
\hline 21580 & Nitzschia archibaldii & 2 & 1 & 0.11 \\
\hline 21580 & Nitzschia dissipata & 3 & 60 & 6.73 \\
\hline 21580 & Nitzschia fonticola & 3 & 1 & 0.11 \\
\hline
\end{tabular}




\begin{tabular}{|l|r|r|r|}
\hline Sample Genus/Species Variety & Pollution Tolerance Class & Count & Percent \\
\hline 215801 Nitzschia heufleriana & 3 & 1 & 0.11 \\
\hline 215801 Nitzschia inconspicua & 2 & 2 & 0.22 \\
\hline 215801 Nitzschia lacuum & 3 & 3 & 0.34 \\
\hline 215801 Nitzschia paleacea & 2 & 7 & 0.78 \\
\hline 215801 Nitzschia perminuta & 3 & 9 & 1.01 \\
\hline 215801 Nitzschia pura & 2 & 5 & 0.56 \\
\hline 215801 Nitzschia pusilla & 1 & 2 & 0.22 \\
\hline 215801 Nitzschia sociabilis & 2 & 3 & 0.34 \\
\hline 215801 Nitzschia subacicularis & 2 & 0 & 0.00 \\
\hline 215801 Pinnularia appendiculata & 3 & 2 & 0.22 \\
\hline 215801 Placoneis clementioides & 3 & 2 & 0.22 \\
\hline 215801 Placoneis exigua & 3 & 0 & 0.00 \\
\hline 215801 Psammothidium helveticum & 3 & 0 & 0.00 \\
\hline 215801 Pseudostaurosira brevistriata & 3 & 28 & 3.14 \\
\hline 215801 Reimeria sinuata & 3 & 10 & 1.12 \\
\hline 215801 Rhopalodia gibba & 2 & 5 & 0.56 \\
\hline 215801 Sellaphora pupula & 2 & 0 & 0.00 \\
\hline 215801 Staurosira construens & 2 & 75 & 8.41 \\
\hline 215801 Staurosirella lapponica & 3 & 0.34 \\
\hline 215801 Staurosirella leptostauron & 3 & 2.69 \\
\hline 215801 Staurosirella pinnata & 3 & 6.39 \\
\hline 215801 Surirella sp. & 3 & 2 & 0.22 \\
\hline 215801 Synedra rumpens & 2 & 2 & 14 \\
\hline 215801 Synedra ulna & 2 & 2.02 \\
\hline
\end{tabular}




\begin{tabular}{|c|c|c|c|}
\hline Genusi5peciesNariely & Pollution Tolerance Class & Count & Percent \\
\hline 215901 Achnanthes lanceolata & 2. & 9 & 0.94 \\
\hline 215901 Achnanthes sp. & 3 & 3 & 0.31 \\
\hline 215901 Achnanthidium biasolettianum & 3. & 5 & 0.52 \\
\hline 215901 Achnanthidium minutissimum & 3. & 193. & 20.23 \\
\hline 215901 Amphora pediculus & 3. & 5 & 0.52 \\
\hline 215901 Aulacoseira canadensis & 3 & 1 & 0.10 \\
\hline 215901 Caloneis bacillum & 2. & 4 & 0.42 \\
\hline 215901 Caloneis silicula & 2. & 3. & 0.31 \\
\hline 215901 Cocconeis pediculus & 3. & 1. & 0.10 \\
\hline 215901 Cocconeis placentula & 3 & 90. & 9.43 \\
\hline 215901 Cyclotella atomus & 2 & 3. & 0.31 \\
\hline 215901 Cymbella hebridica & 3. & 2. & 0.21 \\
\hline 215901Diatoma hiemale & 3 & 16 & 1.68 \\
\hline 215901 Diatoma mesodon & 3. & 29 & 3.04 \\
\hline 215901 Diatoma vulganis & 3 & 4 & 0.42 \\
\hline 215901 Diatomella balfouriana & 3 & 2. & 0.21 \\
\hline 215901Encyonema silesiacum & 2. & 32 & 3.35 \\
\hline 215901Epithemia adnata & 2 & 2 & 0.21 \\
\hline 215901 Fragilaria capucina & 2 & 2 & 0.21 \\
\hline 215901 Fragilaria vaucheriae & 2. & 2 & 0.21 \\
\hline 215901 Gomphonema angustatum & 2 & 244 & 25.58 \\
\hline 215901 Gomphonema clavatum & 2. & 16 & 1.68 \\
\hline 215901 Gomphonema intricatum & 3. & 13 & 1.36 \\
\hline 215901 Gomphonema kobayasii & 3. & 14 & 1.47 \\
\hline 215901 Gomphonema minutum & 3. & 6 & 0.63 \\
\hline 215901 Gomphonema parvulum & 1 & 6 & 0.63 \\
\hline 215901 Hannaea arcus & 3 & 12 & 1.26 \\
\hline 215901 Hantzschia amphioxys & 2 & 4 & 0.42 \\
\hline 215901 Meridion circulare & 3. & 24 & 2.52 \\
\hline 215901 Navicula capitatoradiata & 2. & 2 & 0.21 \\
\hline 215901 Navicula cryptotenella & 2 & 4 & 0.42 \\
\hline 215901 Navicula ignota & 2 & 2 & 0.21 \\
\hline 215901 Navicula minima & 1. & 2 & 0.21 \\
\hline 215901 Navicula seminulum & 1. & 1. & 0.10 \\
\hline 215901 Navicula sp. & 2. & 2. & 0.21 \\
\hline 215901 Navicula tripunctata & 3. & 1. & 0.10 \\
\hline 215901 Nitzschia fonticola & 3 & 4 & 0.42 \\
\hline 215901 Nitzschia inconspicua & 2 & 2. & 0.21 \\
\hline 215901 Nitzschia linearis & 2. & 1 & 0.10 \\
\hline 215901 Nitzschia perminuta & 3 & 4. & 0.42 \\
\hline 215901 Nitzschia pura & 2 & 2. & 0.21 \\
\hline 215901 Nitzschia sigmoidea & 3. & 1 & 0.10 \\
\hline 215901 Psammothidium ventralis & 3 & 2 & 0.21 \\
\hline 215901 Reimeria sinuata & 3 & 77. & 8.07 \\
\hline 215901 Rhoicosphenia curvata & 3 & 5 & 0.52 \\
\hline 215901 Staurosira construens & 3 & 26 & 2.73 \\
\hline 215901 Staurosirella leptostauron & 3 & 5 & 0.52 \\
\hline 215901 Staurosirella pinnata & 3 & 24. & 2.52 \\
\hline 215901 Stephanodiscus minutus & 2. & 5 & 0.52 \\
\hline 215901 Synedra rumpens & 2. & 1. & 0.10 \\
\hline 215901Synedra ulna & 2. & 34 & 3.56 \\
\hline
\end{tabular}




\begin{tabular}{|c|c|c|c|}
\hline Genusfspeciess Variety & Pollution Toferance Class & Count & Percent \\
\hline 216001 Achnanthes lanceolata & 2 & 5 & 0.51 \\
\hline 216001 Achnanthidium biasolettianum & 3 & 4 & 0.41 \\
\hline 216001 Achnanthidium minutissimum & 3 & 160 & 16.33 \\
\hline 216001 Amphora pediculus & 3 & 0 & 0.00 \\
\hline 216001 Aulacoseira distans & 3 & 0 & 0.00 \\
\hline 216001 Cocconeis placentula & 3 & 2 & 0.20 \\
\hline 216001 Cymbella affinis & 3 & 17 & 1.73 \\
\hline 216001 Cymbella cistula & 3 & 7 & 0.71 \\
\hline 216001 Cymbella cymbiformis & 3 & 2 & 0.20 \\
\hline 216001 Cymbella hebridica & 3 & 6 & 0.61 \\
\hline 216001 Diatoma hiemale & 3 & 2 & 0.20 \\
\hline 216001 Diatoma mesodon & 3 & 2 & 0.20 \\
\hline 216001 Encyonema minutum & 2 & 24 & 2.45 \\
\hline 216001Encyonema silesiacum & 2 & 0 & 0.00 \\
\hline 216001Eucocconeis laevis & 3 & 4 & 0.41 \\
\hline 216001 Fragilaria capucina & 2 & 4 & 0.41 \\
\hline 216001 Fragilaria vaucheriae & 2 & 33 & 3.37 \\
\hline 216001 Gomphonema angustatum & 2 & 47 & 4.80 \\
\hline 216001 Gomphonema intricatum & 3 & 2 & 0.20 \\
\hline 216001 Gomphonema pumilum & 3 & 0 & 0.00 \\
\hline 216001 Hannaea arcus & 3 & 482 & 49.18 \\
\hline 216001 Meridion circulare & 3 & 7 & 0.71 \\
\hline 216001 Navicula cari & 2 & 1 & 0.10 \\
\hline 216001 Navicula contenta & 2 & 2 & 0.20 \\
\hline 216001 Navicula cryptotenella & 2 & 3 & 0.31 \\
\hline 216001 Navicula minima & 1 & 2 & 0.20 \\
\hline 216001 Navicula minuscula & 1 & 2 & 0.20 \\
\hline 216001 Navicula reichardtiana & 2 & 3 & 0.31 \\
\hline 216001 Nitzschia fonticola & 3 & 6 & 0.61 \\
\hline 216001 Sellaphora bacillum & 3 & 0 & 0.00 \\
\hline 216001 Staurosira construens & 3 & 21 & 2.14 \\
\hline 216001 Staurosirella lapponica & 3 & 4 & 0.41 \\
\hline 216001 Staurosirella pinnata & 3 & 27 & 2.76 \\
\hline 216001 Synedra rumpens & 2 & 23 & 2.35 \\
\hline 216001 Synedra ulna & 2 & 76 & 7.76 \\
\hline
\end{tabular}




\begin{tabular}{|c|c|c|c|c|}
\hline Sample & GenusfSpecies Variety & Pollution Tolerance Class & Count & Percent \\
\hline \multicolumn{2}{|c|}{ 216101 Achnanthes lanceolata } & 2 & 50 & 5.98 \\
\hline \multicolumn{2}{|c|}{216101 Achnanthidium biasolettianum } & 3 & 0 & 0.00 \\
\hline \multicolumn{2}{|c|}{216101 Achnanthidium minutissimum } & 3 & 14 & 1.67 \\
\hline \multicolumn{2}{|c|}{ 216101 Amphipleura pellucida } & 2 & 6 & 0.72 \\
\hline \multicolumn{2}{|c|}{ 216101 Aulacoseira canadensis } & 3 & 1. & 0.12 \\
\hline \multicolumn{2}{|c|}{ 216101 Aulacoseira islandica } & 3 & 1 & 0.12 \\
\hline \multicolumn{2}{|c|}{216101 Caloneis bacillum } & 2 & 0 & 0.00 \\
\hline \multicolumn{2}{|c|}{216101 Cocconeis placentula } & 3 & 41 & 4.90 \\
\hline \multicolumn{2}{|c|}{216101 Diatoma mesodon } & 3 & 4 & 0.48 \\
\hline \multicolumn{2}{|c|}{ 216101 Diploneis elliptica } & 3 & 1. & 0.12 \\
\hline \multicolumn{2}{|c|}{216101 Encyonema auerswaldii } & 2 & 4 & 0.48 \\
\hline \multicolumn{2}{|c|}{ 216101:Epithemia turgida } & 3 & 5 & 0.60 \\
\hline \multicolumn{2}{|c|}{216101 Fragilania capucina } & 2 & 13 & 1.56 \\
\hline \multicolumn{2}{|c|}{216101 Gomphonema angustatum } & 2 & 29 & 3.47 \\
\hline \multicolumn{2}{|c|}{216101 Gomphonema mexicanum } & 2 & 2 & 0.24 \\
\hline \multicolumn{2}{|c|}{216101 Gomphonema pumilum } & 3 & 4 & 0.48 \\
\hline \multicolumn{2}{|c|}{ 216101 Meridion circulare } & 3 & 391 & 46.77 \\
\hline \multicolumn{2}{|c|}{ 216101 Navicula cryptocephala } & 3 & 3 & 0.36 \\
\hline \multicolumn{2}{|c|}{ 216101 Navicula cryptotenella } & 2 & 3 & 0.36 \\
\hline \multicolumn{2}{|c|}{216101 Navicula minima } & 1 & 59 & 7.06 \\
\hline \multicolumn{2}{|c|}{216101 Navicula reichardtiana } & 2 & 7 & 0.84 \\
\hline \multicolumn{2}{|c|}{216101 Navicula tripunctata } & 3 & 8 & 0.96 \\
\hline \multicolumn{2}{|c|}{216101 Nitzschia communis } & 1 & 4 & 0.48 \\
\hline \multicolumn{2}{|c|}{216101 Nitzschia dissipata } & 3 & 27 & 3.23 \\
\hline \multicolumn{2}{|c|}{216101 Nitzschia fonticola } & 3 & 1 & 0.12 \\
\hline \multicolumn{2}{|c|}{ 216101 Rhoicosphenia curvata } & 3 & 9 & 1.08 \\
\hline \multicolumn{2}{|c|}{216101 Sellaphora bacillum } & 3 & 2. & 0.24 \\
\hline \multicolumn{2}{|c|}{216101 Staurosira construens } & 3 & 7 & 0.84 \\
\hline \multicolumn{2}{|c|}{216101 Synedra ulna } & 2 & 140 & 16.75 \\
\hline
\end{tabular}




\begin{tabular}{|c|c|c|c|}
\hline Genus/Species Varieny & Pollution Tolerance Class & Count & Percent \\
\hline 216201 Achnanthes lanceolata & 2 & 47. & 4.76 \\
\hline 216201 Achnanthidium affine & 3 & 6 & 0.61 \\
\hline 216201 Achnanthidium biasolettianum & 3. & 11 & 1.11 \\
\hline 216201 Achnanthidium minutissimum & 3 & 256 & 25.94 \\
\hline 216201 Amphora inariensis & 3 & 0 & 0.00 \\
\hline 216201 Amphora pediculus & 3 & 9. & 0.91 \\
\hline 216201 Caloneis bacillum & 2 & 10 & 1.01 \\
\hline 216201 Cocconeis placentula & 3 & 27. & 2.74 \\
\hline 216201 Cymbella hebridica & 3. & 24 & 2.43 \\
\hline 216201 Diatoma hiemale & 3. & 27 & 2.74 \\
\hline 216201 Diatoma mesodon & 3 & 16 & 1.62 \\
\hline 216201 Encyonema lunatum & 3 & 2 & 0.20 \\
\hline 216201 Encyonema minutum & 2 & 55 & 5.57 \\
\hline 216201 Encyonema muelleri & 2 & 2 & 0.20 \\
\hline 216201 Encyonema prostratum & 3. & 2. & 0.20 \\
\hline 216201 Encyonema reichardtii & 3. & 2 & 0.20 \\
\hline 216201Encyonema silesiacum & 2 & 17 & 1.72 \\
\hline 216201 Encyonopsis microcephala & 2 & 2 & 0.20 \\
\hline 216201 Fragilaria capucina & 2 & 8. & 0.81 \\
\hline 216201 Fragilaria vaucheriae & 2 & 21 & 2.13 \\
\hline 216201 Frustulia rhomboides & 3 & 1 & 0.10 \\
\hline 216201 Gomphonema angustatum & 2 & 59 & 5.98 \\
\hline 216201 Gomphonema kobayasii & 3 & 2 & 0.20 \\
\hline 216201 Gomphonema olivaceoides & 3. & 2 & 0.20 \\
\hline 216201 Hannaea arcus & 3 & 17 & 1.72 \\
\hline 216201 Meridion circulare & 3 & 10 & 1.01 \\
\hline 216201 Navicula acceptata & 2. & 1 & 0.10 \\
\hline 216201 Navicula cryptocephala & 3. & 0 & 0.00 \\
\hline 216201 Navicula cryptotenella & 2. & 31 & 3.14 \\
\hline 216201 Navicula menisculus & 2 & 1 & 0.10 \\
\hline 216201 Navicula minima & 1 & 10 & 1.01 \\
\hline 216201 Navicula minuscula & 1 & 2 & 0.20 \\
\hline 216201 Navicula reichardtiana & 2 & 60 & 6.08 \\
\hline 216201 Navicula tripunctata & 3 & 69 & 6.99 \\
\hline 216201 Nitzschia archibaldii & 2 & 1 & 0.10 \\
\hline 216201 Nitzschia dissipata & 3 & 19. & 1.93 \\
\hline 216201 Nitzschia fonticola & 3 & 19 & 1.93 \\
\hline 216201 Nitzschia heufleriana & 3 & 10 & 1.01 \\
\hline 216201 Nitzschia linearis & 2 & 18 & 1.82 \\
\hline 216201 Nitzschia pura & 2 & 22 & 2.23 \\
\hline 216201 Reimeria sinuata & 3. & 5 & 0.51 \\
\hline 216201Rhoicosphenia curvata & 3 & 6 & 0.61 \\
\hline 216201 Staurosira construens & 3 & 1. & 0.10 \\
\hline 216201 Staurosirella leptostauron & 3 & 18 & 1.82 \\
\hline 216201 Staurosirella pinnata & 3 & 6 & 0.61 \\
\hline 216201 Surirella angusta & 1 & 0 & 0.00 \\
\hline 216201 Surirella minuta & 2 & 2 & 0.20 \\
\hline 216201 Synedra rumpens & 2 & 3 & 0.30 \\
\hline 216201 Synedra ulna & 2 & 48 & 4.86 \\
\hline
\end{tabular}




\begin{tabular}{|c|c|c|c|c|}
\hline Sample & Genus/SpeciesNariety & Pollution Tolerance Class & Count & Percent \\
\hline \multicolumn{2}{|c|}{ 216301 Achnanthes lanceolata } & 2 & $73 !$ & 795 \\
\hline \multirow{2}{*}{\multicolumn{2}{|c|}{$\begin{array}{l}216301 \text { Achnanthidium affine } \\
216301 \text { Achnanthidium minutissimum }\end{array}$}} & 3 & 2 & 0.22 \\
\hline & & 3 & 159 & 17.32 \\
\hline \multicolumn{2}{|c|}{$\begin{array}{l}\text { 216301. Achnanthidum minutissimum } \\
\text { 215301 Amphipleura_pellucida }\end{array}$} & 2 & 2 & 022 \\
\hline \multicolumn{2}{|c|}{ 216301 Amphora pediculus } & 3 & 4 & 0.44 \\
\hline \multicolumn{2}{|c|}{ 216301 Aulacoseira distans } & 3 & 1. & 0.11 \\
\hline \multicolumn{2}{|c|}{216301 Caloneis bacillum } & 2 & 1. & 0.11 \\
\hline \multirow{2}{*}{\multicolumn{2}{|c|}{ 216301. Caloneis silicula }} & 2 & 0 & 0.00 \\
\hline & & 3. & 14. & 1.53 \\
\hline \multicolumn{2}{|c|}{$\begin{array}{l}\text { 216301 Cocconeis placentula } \\
216301 \text { Cymbella aspera }\end{array}$} & 3 & 2 & 0.22 \\
\hline \multicolumn{2}{|c|}{216301 Cymbella cistula } & 3 & 6 & 0.65 \\
\hline \multicolumn{2}{|c|}{216301 cymbella hebridica } & 3 & 5 & 0.54 \\
\hline \multicolumn{2}{|c|}{216301 Diadesmis contenta } & 2 & 2 & 0.22 \\
\hline \multicolumn{2}{|c|}{ 216301Diadesmis perpusilla } & 2 & 8 & 0.87 \\
\hline \multicolumn{2}{|c|}{ 216301Diatoma hiemale } & 3 & 21. & 2.29 \\
\hline \multicolumn{2}{|c|}{ 216301Diatoma mesodon } & 3 & 54 & 5.88 \\
\hline \multicolumn{2}{|c|}{216301 Encyonema minutum } & 2 & 5 & 0.54 \\
\hline 21630 & Encyonema silesiacum. & 2 & 25 & 2.72 \\
\hline 21630 & Epithemia turgida & 3. & 0 & 0.00 \\
\hline 21630 & Fragilaria capucina & 2 & 43 & 4.68 \\
\hline 21630 & Fragilaria vaucheriae & 2 & 6 & 0.65 \\
\hline 21630 & Frustulia vulgaris & 2 & 2 & 0.22 \\
\hline 21630 & Gomphonema angustatum & 2 & 0 & 000 \\
\hline 21630 & Gomphonema brebissonii & 3 & 0 & 0.00 \\
\hline 21630 & Gomphonema clavatum & 2 & 1 & 0.11 \\
\hline 21630 & Gomphonema kobayasii & 3 & 14 & 153 \\
\hline 21630 & Gomphonema micropus & 2. & 6 & 0.65 \\
\hline 21630 & Gomphonema minutum & 3 & 2. & 0.22 \\
\hline 21630 & Gomphonema olivaceoides & 3 & 2. & 0.22 \\
\hline 21630 & Gomphonema sarcophagus & 2 & 3 & 0.33 \\
\hline 21630 & Gomphonema truncatum & 3 & 0 & 0.00 \\
\hline 21630 & Hannaea arcus & 3 & 9 & 0.98 \\
\hline 21630 & Melosira varians & 2 & 11. & 1.20 \\
\hline 21630 & Meridion circulare & 3 & 136 & 14.81 \\
\hline 21630 & Navicula cryptocephala & 3 & 5 & 0.54 \\
\hline 21630 & Navicula_libonensis & 2 & 2 & 0.22 \\
\hline 21630 & Navicula minima & 1. & 13. & 1.42 \\
\hline 21630 & Navicula minuscula & 1. & 6 & 0.65 \\
\hline 21630 & Navicula pelliculosa & 1 & 2 & 0.22 \\
\hline 21630 & Navicula radiosa & 3 & 1. & 011 \\
\hline 21630 & Navicula reichardtiana & 2 & 43 & 4.68 \\
\hline 21630 & Navicula tripunctata & 3 & 4. & 0.44 \\
\hline 21630 & Navicula trivialis & 2 & 0 & 0.00 \\
\hline 21630 & Nitzschia acicularis & 2 & 1. & 0.11 \\
\hline 21630 & Nitzschia archibaldii & 2 & 9 & 0.98 \\
\hline 21630 & Nitzschia dissipata & 3 & 26 & 283 \\
\hline 21630 & Nitzschia fonticola & 3 & 5 & 0.54 \\
\hline 21630 & Nitzschia frustulum & 2 & 2 & 0.22 \\
\hline 21630 & Nitzschia heufleriana & 3 & 1 & 0.11 \\
\hline 21630 & Nitzschia linearis & 2 & 10 & 109 \\
\hline 21630 & Nitzschia palea & 1 & 0 & 0.00 \\
\hline 21630 & Nitzschia perminuta & 3 & 2 & 0.22 \\
\hline 21630 & Nitzschia pura & 2 & 4 & 0.44 \\
\hline 21630 & Reimeria sinuata & 3 & 3 & 0.33 \\
\hline 21630 & Rhoicosphenia curvata & 3 & 2 & 0.22 \\
\hline 21630 & Staurosira construens & 3 & 31 & 3.38 \\
\hline 21630 & Staurosirella leptostauron & 3 & 7 & 0.76 \\
\hline 21630 & Staurosirella pinnata & 3 & 17 & 185 \\
\hline 21630 & Surirella angusta & 1 & 0 & \\
\hline 21630 & Surirella minuta & 2 & 0 & 0.00 \\
\hline 21630 & Surirella sp. & 2 & 2 & 0.22 \\
\hline 21630 & Synedra rumpens & 2 & 60 & 6.54 \\
\hline 21630 & Synedra ulna & 2 & 41 & \\
\hline
\end{tabular}




\begin{tabular}{|c|c|c|c|}
\hline Genus/SpeciesNariety & Polfution Tolerance Class & Count. & Percent \\
\hline 216401Achnanthes exigua & 3 & 0. & 0.00 \\
\hline 216401 Achnanthes lanceolata & 2 & 29 & 3.08 \\
\hline 216401 Achnanthes sp. & 3 & 6 & 0.64 \\
\hline 216401 Achnanthes thermalis & 3 & 2. & 0.21 \\
\hline 216401/Achnanthidium minutissimum & 3 & 38. & 4.03 \\
\hline 216401 Amphipleura pellucida & 2 & 4 & 0.42 \\
\hline 216401 Amphora pediculus & 3 & 2 & 0.21 \\
\hline 216401/Aulacoseira distans & 3 & 0 & 0.00 \\
\hline 216401Caloneis_bacillum & 2 & 4 & 0.42 \\
\hline 216401. Cocconeis placentula & 3 & 2. & 0.21 \\
\hline 216401Diatoma mesodon & 3 & 25 & 2.65 \\
\hline 216401Diploneis oculata & 3. & 2 & 0.21 \\
\hline 216401Encyonema silesiacum. & 2 & 4 & 0.42 \\
\hline 216401 Encyonopsis microcephala & 2 & 2 & 0.21 \\
\hline 216401 Eucocconeis laevis & 3 & 1. & 0.11 \\
\hline 216401Eunotia bilunaris & 3 & 5 & 0.53 \\
\hline 216401Eragilaria crotonensis & 3. & 0 & 0.00 \\
\hline 216401Eragilaria vaucheriae & 2 & 4 & 0.42 \\
\hline 216401.Frustulia vulgaris & 2 & 4 & 0.42 \\
\hline 216401 Gomphonema angustatum & 2 & 5 & 0.53 \\
\hline 216401.Gomphonema brebissonii & 3 & 1. & 0.11 \\
\hline 216401 Gomphonema micropus & 2 & 0 & 0.00 \\
\hline 216401 Gomphonema minutum. & 3 & 2 & 0.21 \\
\hline 216401 Gomphonema parvulum & 1 & 2 & 0.21 \\
\hline 216401.Gomphonema pumilum & 3 & 4. & 0.42 \\
\hline 216401 Hannaea arcus & 3 & 16 & 1.70 \\
\hline 216401Meridion circulare & 3 & 56. & 5.94 \\
\hline 216401 Navicula acceptata & 2 & 2 & 0.21 \\
\hline 216401 Navicula arvensis & 1 & 9. & 0.96 \\
\hline 216401 Navicula cryptocephala & 3 & 2 & 0.21 \\
\hline 216401 Navicula cryptotenella & 2 & 4 & 0.42 \\
\hline 216401 Navicula medioconvexa & 3. & 4. & 0.42 \\
\hline 216401 Navicula minima & 1 & 26 & 276 \\
\hline 216401Navicula_protracta & 2 & 2 & 0.21 \\
\hline 216401 Navicula radiosa & 3 & 4 & 0.42 \\
\hline 216401 Navicula reichardtiana & 2 & 4 & 0.42 \\
\hline 216401 Nitzschia acicularis & 2 & 10 & 1.06 \\
\hline 216401Nitzschia_archibaldii & 2 & 87 & 9.24 \\
\hline 216401 Nitzschia dissipata. & 3. & 6 & 0.64 \\
\hline 216401Nitzschia flexoides & 2. & 2. & 0.21 \\
\hline 216401 Nitzschia fonticola & 3. & 22. & 234 \\
\hline 216401 Nitzschia frustulum & 2 & 2 & 0.21 \\
\hline 216401 Nitzschia graciliformis & 2 & 0. & 0.00 \\
\hline 216401 Nitzschia_lacuum & 3. & 2. & 0.21 \\
\hline 216401 Nitzschia palea & 1 & 4. & 0.42 \\
\hline 216401 Nitzschia pura & 2 & 4 & 0.42 \\
\hline 216401Psammothidium bioretii & 3 & 3 & 0.32 \\
\hline 216401Pseudostaurosira brevistriata & 3. & 64 & 6.79 \\
\hline 216401Rhoicosphenia curvata & 3 & 5 & 0.53 \\
\hline 216401 Sellaphora pupula & 2. & 2 & 0.21 \\
\hline 216401 Staurosira construens & 3 & 260 & 2760 \\
\hline 216401 Staurosirella leptostauron & 3. & 2 & 0.21 \\
\hline 216401 Staurosirella pinnata & 3. & 24. & 255 \\
\hline 216401 Synedra parasitica & 2 & 12 & 1.27 \\
\hline 216401 Synedra rumpens & 2 & 128 & 13.59 \\
\hline 216401 Synedra tenera & 2. & 0 & 0.00 \\
\hline 216401 Synedra ulna & 2 & 26 & 276 \\
\hline
\end{tabular}




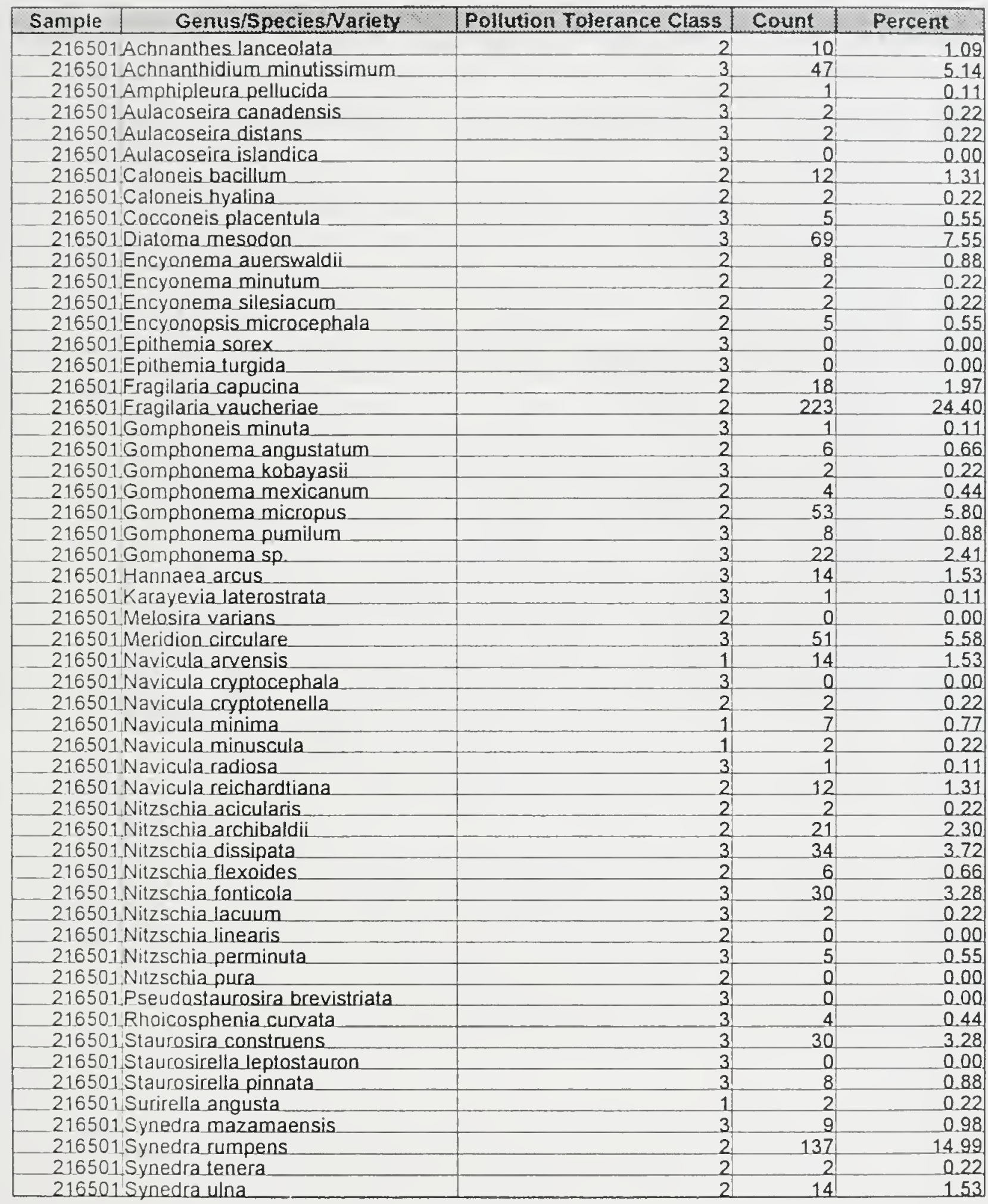




\begin{tabular}{|c|c|c|c|}
\hline Genus/SpeciesNariety & Pollution Tolerance Class & Count & Percent \\
\hline 216601 Achnanthes biconfusa & 3 & 8 & 0.96 \\
\hline 216601 Achnanthes lanceolata & 2 & 31 & 3.71 \\
\hline 216601 Achnanthidium biasolettianum & 3 & 3 & 0.36 \\
\hline 216601 Achnanthidium minutissimum & 3 & 165 & 19.74 \\
\hline 216601 Caloneis tenuis & 3 & 8 & 0.96 \\
\hline 216601 Diatoma mesodon & 3 & 434 & 51.91 \\
\hline 216601Encyonema minutum & 2 & 2 & 0.24 \\
\hline 216601Encyonema silesiacum & 2 & 4. & 0.48 \\
\hline 216601Epithemia adnata & 2 & 2 & 0.24 \\
\hline 216601 Eunotia bilunaris & 3 & 4 & 0.48 \\
\hline 216601 Eunotia minor & 2 & 1 & 0.12 \\
\hline 216601 Gomphonema angustatum & 2 & 1 & 0.12 \\
\hline 216601 Gomphonema clavatum & 2 & 4 & 0.48 \\
\hline 216601 Gomphonema pumilum & 3 & 8 & 0.96 \\
\hline 216601 Meridion circulare & 3 & 12 & 1.44 \\
\hline 216601 Navicula atomus & 1 & 1 & 0.12 \\
\hline 216601 Navicula cryptocephala & 3 & 3 & 0.36 \\
\hline 216601 Navicula minima & 1 & 48 & 5.74 \\
\hline 216601 Navicula radiosa & 3 & 0 & 0.00 \\
\hline 216601 Nitzschia archibaldii & 2 & 5 & 0.60 \\
\hline 216601 Nitzschia dissipata & 3 & 4 & $0 . \overline{48}$ \\
\hline 216601 Nitzschia fonticola & 3 & 2 & 0.24 \\
\hline 216601 Staurosira construens & 3 & 5 & 0.60 \\
\hline 216601 Synedra rumpens & 2 & 81 & 9.69 \\
\hline
\end{tabular}




\begin{tabular}{|c|c|c|c|}
\hline Genus/SpeciesNariety & Pollution Tolerance Class & Count & Percent \\
\hline 216701 Achnanthes lanceolata & 2 & 2 & 0.23 \\
\hline 216701 Achnanthidium biasolettianum & 3 & 0 & 0.00 \\
\hline 216701 Achnanthidium minutissimum & 3 & 742 & 86.48 \\
\hline 216701 Aulacoseira distans & 3 & 0 & 0.00 \\
\hline 216701 Caloneis tenuis & 3 & 0 & 0.00 \\
\hline 216701 Cymbella naviculiformis & 3 & 0 & 0.00 \\
\hline 216701 Diatoma mesodon & 3 & 15 & 1.75 \\
\hline 216701 Fragilaria capucina & 2 & 2 & 0.23 \\
\hline 216701 Frustulia rhomboides & 3 & 0 & 0.00 \\
\hline 216701 Gomphonema acuminatum & 3 & 1 & 0.12 \\
\hline 216701 Gomphonema clavatum & 2 & 0 & 0.00 \\
\hline 216701 Gomphonema mexicanum & 2 & 0 & 0.00 \\
\hline 216701 Gomphonema parvulum & 1 & 2 & 0.23 \\
\hline 216701 Gomphonema pumilum & 3 & 2 & 0.23 \\
\hline 216701 Meridion circulare & 3 & 0 & 0.00 \\
\hline 216701 Navicula cryptocephala & 3 & 2 & 0.23 \\
\hline 216701 Navicula minima & 1 & 16 & 1.86 \\
\hline 216701 Navicula seminulum & 1 & 2. & 0.23 \\
\hline 216701 Nitzschia acicularis & 2 & 2 & 0.23 \\
\hline 216701 Nitzschia archibaldii & 2 & 0 & 0.00 \\
\hline 216701 Nitzschia dissipata & 3 & 0 & 0.00 \\
\hline 216701 Nitzschia flexoides & 2 & 0 & 0.00 \\
\hline 216701 Nitzschia palea & 1 & 0 & 0.00 \\
\hline 216701 Nitzschia pura & 2 & 2 & 0.23 \\
\hline 216701 Pinnularia microstauron & 2 & 1 & 0.12 \\
\hline 216701 Pseudostaurosira brevistriata & 3 & 6 & 0.70 \\
\hline 216701 Sellaphora bacillum & 3 & 0 & 0.00 \\
\hline 216701 Sellaphora pupula & 2 & 0 & 0.00 \\
\hline 216701 Staurosira construens & 3 & 41 & 4.78 \\
\hline 216701 Staurosirella pinnata & 3 & 0 & 0.00 \\
\hline 216701 Surirella angusta & 1 & 0 & 0.00 \\
\hline 216701 Synedra rumpens & 2 & 20 & 2.33 \\
\hline
\end{tabular}


